FEDERAL RESERVE BANK OF SAN FRANCISCO

WORKING PAPER SERIES

\title{
The Great Mortgaging: Housing Finance, Crises, and Business Cycles
}

\author{
Òscar Jordá \\ Federal Reserve Bank of San Francisco \\ Moritz Schularick \\ Department of Economics, University of Bonn \\ Alan M. Taylor \\ Department of Economics and Graduate School of Management, \\ University of California, Davis, NBER and CEPR
}

September 2014

Working Paper 2014-23

http://www.frbsf.org/economic-research/publications/working-papers/wp2014-23.pdf

The views in this paper are solely the responsibility of the authors and should not be interpreted as reflecting the views of the Federal Reserve Bank of San Francisco or the Board of Governors of the Federal Reserve System. 


\title{
The Great Mortgaging: Housing Finance, Crises, and Business Cycles*
}

\author{
Òscar Jordà ${ }^{+}$
}

\author{
Moritz Schularick $\ddagger$ \\ September 2014
}

\author{
Alan M. Taylor $\S$
}

\begin{abstract}
This paper unveils a new resource for macroeconomic research: a long-run dataset covering disaggregated bank credit for 17 advanced economies since 1870 . The new data show that the share of mortgages on banks' balance sheets doubled in the course of the 2oth century, driven by a sharp rise of mortgage lending to households. Household debt to asset ratios have risen substantially in many countries. Financial stability risks have been increasingly linked to real estate lending booms which are typically followed by deeper recessions and slower recoveries. Housing finance has come to play a central role in the modern macroeconomy.
\end{abstract}

Keywords: leverage, recessions, mortgage lending, financial crises, business cycles, local projections.

JEL Codes: C14, C38, C52, E32, E37, E44, E51, Go1, G21, N10, N20.

\footnotetext{
${ }^{*}$ The views expressed herein are solely the responsibility of the authors and should not be interpreted as reflecting the views of the Federal Reserve Bank of San Francisco or the Board of Governors of the Federal Reserve System. We are particularly grateful to a large number of researchers at universities and central banks around the world who helped with the construction of the historical dataset. Details can be found in the appendix. We wish to thank Philip Jung, Atif Mian and Gernot Mueller for helpful comments and Katharina Knoll for sharing data on home ownership rates and housing wealth. The authors gratefully acknowledge financial support from the Institute for New Economic Thinking (INET) administered by UC Davis. Schularick received financial support from the Volkswagen Foundation. This research was undertaken while Schularick was a Research Fellow of Hong Kong Institute for Monetary Research (HKIMR). The generous support of the HKIMR is gratefully acknowledged. Early Elias and Niklas Flamang provided outstanding research assistance. All errors are ours.

${ }^{\dagger}$ Federal Reserve Bank of San Francisco; and Department of Economics, University of California, Davis (oscar.jorda@sf.frb.org; ojorda@ucdavis.edu).

‡Department of Economics, University of Bonn; and CEPR (moritz.schularick@uni-bonn.de).

$\S$ Department of Economics and Graduate School of Management, University of California, Davis; NBER; and CEPR (amtaylor@ucdavis.edu).
} 


\section{INTRODUCTION}

The past three decades have seen an unprecedented surge in the scale and scope of financial activities in advanced economies-a process that is sometimes referred to as financialization. Its effects continue to be contentiously debated.

Financialization shows up in the rising income share of finance (Greenwood and Scharfstein 2013; Philippon and Resheff 2013), the ascent of household debt (Mian and Sufi 2014), as well as the growth of the volume of financial claims on the balance sheets of financial intermediaries (Schularick and Taylor 2012; Jordà, Schularick, and Taylor 2013). The increasing size and leverage of the financial sector has been interpreted as an indicator of excessive risk taking (Admati and Hellwig 2013; Aikman, Haldane, and Nelson 2014) and has been linked to the increase in income inequality in advanced economies (Piketty 2013; Godechot 2012), as well as to the growing political influence of the financial industry (Johnson and Kwak 2010). Clearly, understanding the causes and consequences of the growth of finance is a first order concern for macroeconomists and policymakers. Yet surprisingly little is known about the driving forces of these important new trends in modern financial history.

This paper studies these issues through the lens of long-run macroeconomic history. Our first contribution is to unveil a new resource for macroeconomic research: a long-run dataset on disaggregated bank credit for 17 advanced economies since 1870 . The dataset is the result of a large-scale investigative process and an extensive standardization effort to produce consistent time series. In addition to our new credit variables the dataset also contains a rich set of macroeconomic controls. The new data allow us to delve much deeper into the driving forces of financialization than has been possible until now.

The database that we provide covers disaggregated bank balance sheet data at annual frequency for the near universe of industrial countries since 1870. In particular, we study the development of various subcomponents of loans on banks' balance sheets-secured 
and unsecured lending as well as lending to businesses and households-over a span of 140 years. We document the rising share of real estate lending (i.e., bank loans secured against real estate) in total bank credit and the declining share of unsecured credit to businesses and households. We also document long-run sectoral trends in lending to companies and households (albeit for a somewhat shorter time span), which suggest that the growth of finance has been closely linked to an explosion of mortgage lending to households in the last quarter of the 2oth century. The key facts that the new data allow us to establish can be summarized as follows.

First, we demonstrate that the sharp increase of credit-to-GDP ratios in advanced economies in the 20th century has been first and foremost a result of the rapid growth of loans secured on real estate, i.e., mortgage and hypothecary lending. The share of mortgage loans in banks' total lending portfolios has roughly doubled over the course of the past century-from about $30 \%$ in 1900 to about $60 \%$ today. To a large extent the core business model of banks in advanced economies today resembles that of real estate funds: banks are borrowing (short) from the public and capital markets to invest (long) into assets linked to real estate.

Second, looking more deeply at the composition of bank credit, it becomes clear that the rapid growth of mortgage lending to households has been the driving force behind this remarkable change in the composition of banks' balance sheets. The intermediation of household savings for productive investment in the business sector-the standard textbook role of the financial sector-constitutes only a minor share of the business of banking today, even though it was a central part of that business in the 19th and early 2oth centuries. We also find that household mortgage debt has risen faster than asset values in many countries resulting in record-high leverage ratios that potentially increase the fragility of household balance sheets and the financial system itself. Complementing the recent influential work of Mian and Sufi (2014) for the United States, our work takes a

\footnotetext{
${ }^{1}$ We will use the terms "mortgage lending" and "real estate lending" interchangeably in this paper.
} 
longer and wider view to show that the blowing up and bursting of private credit booms centered on aggressive mortgage expansion reflects deep processes at work across all of the advanced countries, and building up persistently across the entire post-WWII period.

Third, we demonstrate that the shifts in the composition of banks' balance sheets have important consequences for our understanding of the source of financial instability. Mortgage lending booms were only loosely associated with financial crisis risks before WWII, but real estate credit has become a more important predictor of impeding financial fragility in the postwar era. From the perspective of policymakers aiming to design new macro-prudential policies today, our work confirms the crucial role of mortgage credit in the buildup of financial fragility.

Fourth, by using our new disaggregated credit data we can robustly demonstrate that the magnitude and structure of credit booms have important consequences for business-cycle dynamics. Reinhart and Rogoff $(2009,215-20)$ argued that financial crisis recessions may have a tendency to be long and painful, a conjecture based on simple path averages for a sample of 18 postwar bank-centered financial cases in advanced economies. Here, with our granular historical dataset, we perform more formal benchmarking and statistical analysis for the near-universe of advanced-country macroeconomic performance since 1870, covering over $90 \%$ of advanced economy output, and encompassing up to 200 recession episodes, with $1 / 4$ of them linked to a financial crisis and $3 / 4$ being normal cycles..$^{2}$

With sample size comes statistical power, and our hypothesis tests show that the typical output path during recession and recovery in financial-crisis recessions is significantly worse than in normal recessions, amounting to a cumulative loss of $20 \%$ of annual output

\footnotetext{
${ }^{2}$ Note that we focus on advanced economies only, as in Reinhart and Rogoff (2009, Chapter 13). In their next chapter (p. 223) they explain that they exclude emerging economies from the sample so as "not to appear to engage in hyperbole." Their analysis including emerging economies shows similar but stronger patterns of deeper recessions. This echoes previous studies, e.g., Cerra and Saxena (2008), and several papers from the BIS, IMF, and other organizations. Our view is that given the institutional and other differences between advanced and emerging economies which may create greater output volatility in the latter group (Acemoglu et al. 2003) it is preferable to conduct analysis on a long-narrow panel of advanced economies rather than a short-wide panel which pools together both advanced and emerging economies which may be structurally different. With a smaller $N$, we need larger $T$ in order to have statistical power, leading to the historical approach which we have followed here.
} 
over 5 years. But why is there such a negative effect due to a financial crisis? We use modern methods based on inverse propensity score weighting to argue that it is an effect and that cannot be fully explained away by other (observable) characteristics. Still, one key covariate, credit, is particularly influential in shaping business cycle dynamics. Recessions that follow larger credit booms tend to be significantly worse, all else equal. Furthermore, we can show that contemporary business cycles are predominantly influenced by trends in the mortgage component of credit. Since WWII, it is only the aftermaths of mortgage booms that are marked by deeper recessions and slower recoveries. This is true both in normal cycles and those associated with financial crises.

Our findings echo the developments witnessed in the aftermath of the global financial crisis and also underline the need for additional nuance in monitoring the build-up of financial instability: it is not just a matter of how loose credit is in the aggregate, but also for what kind of purpose it is used.

\section{A New Historical Credit Database}

The data unveiled in this paper are the result of an extensive data collection effort over several years. It covers bank credit to the domestic nonfinancial private sector (business and households) on an annual basis from 1870 to 2011 for the near-universe of advanced economies. The dataset builds on and extends the long-run credit data compiled by Schularick and Taylor (2012), and the updated series in Jordà, Schularick, and Taylor (2013), in three important ways:

1. Disaggregated credit data: The new dataset tracks the development of various types of bank lending. For the first time we can construct the share of mortgage lending in total bank lending for most countries back to the 19th century. In addition, we calculate the share of bank credit to business and households for most of countries for the decades after WWII and back to the 19th century for a handful of countries. 
2. Broader coverage of financial institutions: In addition to commercial banks' balance sheets, our data now include credit extended by savings banks, credit unions, and building societies yielding a more accurate picture of total credit creation by financial intermediaries. Accordingly, we have calculated a new series of total bank lending to the private sector that replaces the older series from Schularick and Taylor (2012). Data constraints prevent us from including direct borrowing in capital markets and private credit contracts between individuals which have been sizable in some countries in the early 19th century (see, e.g. Hoffman, Postel-Vinay, and Rosenthal 2000 for France). However, comparing our annual data to Goldsmith's (1969) decadal benchmark estimates for total credit indicates that our series capture the largest part of total credit for all countries across the sample period.

3. Larger and longer sample: We added bank credit as well macroeconomic control data for Belgium, Finland, and Portugal bringing the total number of countries covered by our database to 17 . The dataset also now extends to the year 2011.

Where do these new data come from? We consulted a broad range of sources, from economic and financial history books and journal articles, publications of statistical offices and central banks, and archival sources at central and private banks. The scale of this data collection effort would not have been possible without the generous support of many colleagues at various research institutions, archives, central banks, and statistical offices who shared their data or directed us to potential sources. We are also heavily indebted to a group of dedicated research assistants in various places who successfully chased often imprecise references through libraries and archives in various countries. Details of the data construction appear in an extensive (100+ pages) online appendix which also acknowledges the support we received from many colleagues.

For some countries we extended existing data series from previous statistical work of financial historians or statistical offices. Such was the case for Australia, Canada, Japan, and the United States. For other countries we relied on recent data collection efforts 
at central banks, such as for Denmark, Italy, and Norway. Sometimes we combined information from a wide range sources and spliced series to create long-run datasets for the first time. Belgium provides a good illustration of the challenges involved. Data on mortgage lending by financial institutions before World War I come from a Germanlanguage dissertation published in 1918; data for the interwar credit market are taken from a recent (2005) reconstruction of Belgian national income accounts undertaken by a group of economic historians at the University of Leuven. Disaggregated data for bank credit in the two decades following WWII come from the Monthly Bulletin of the Belgian National Bank and a statistical publication of the Ministry of Economics respectively. Finally, we relied on unpublished data on mortgage credit for the years 1960-2011 that the Statistics Department of the Belgian National Bank shared with us.

Data on macroeconomic control variables come from our previous dataset, where we relied on the work of economic and financial historians and secondary data collections by Maddison (2005), Barro and Ursúa (2008), and Mitchell (2008abc). As noted, we have now added macroeconomic data for three additional countries, bringing our total to 17 countries, covering most advanced economies.

Table I summarizes the coverage of our database by country and type of credit. Overall, we have found long-run data for most countries for total bank lending and mortgage lending. Disaggregated data for bank credit to companies and households are available for some countries over the entire sample period, and are available in the post-WWII period for the majority of countries.

Figure 1 provides a first comparison of our new bank credit series with the older series taken from our previous dataset which covered predominantly credit by commercial banks. As a consistency check, we also plot alternative post-WWII data that have been recently made available by the Bank for International Settlements (2013). Reassuringly, our new series and the BIS series track each other closely where they overlap. This is true both in aggregate and at the country level. 
Table 1: New credit data in this study: Sample coverage by country

\begin{tabular}{lcccc}
\hline \hline Country & Total loans & Real estate & Households & Business \\
\hline Australia & $1870-2011$ & $1870-2011$ & $1870-2011$ & $1870-2011$ \\
Belgium & $1885-2011$ & $1885-2011$ & $1950-2011$ & $1950-2011$ \\
Canada & $1870-2011$ & $1874-2010$ & $1956-2010$ & $1961-2010$ \\
Switzerland & $1870-2011$ & $1870-2011$ & $1870-2011$ & $1870-2011$ \\
Germany & $1883-2011$ & $1883-2011$ & $1950-2011$ & $1950-2011$ \\
Denmark & $1870-2011$ & $1875-2010$ & $1951-2010$ & $1951-2010$ \\
Spain & $1900-2011$ & $1904-2010$ & $1946-2010$ & $1946-2010$ \\
Finland & $1870-2011$ & $1927-2011$ & $1948-2011$ & $1948-2011$ \\
France & $1900-2011$ & $1870-2010$ & $1958-2010$ & $1958-2010$ \\
United Kingdom & $1880-2011$ & $1880-2011$ & $1880-2011$ & $1880-2011$ \\
Italy & $1870-2012$ & $1870-2010$ & $1950-2010$ & $1950-2010$ \\
Japan & $1888-2011$ & $1893-2011$ & $1948-2011$ & $1948-2011$ \\
Netherlands & $1900-2011$ & $1900-2011$ & $1990-2011$ & $1990-2011$ \\
Norway & $1870-2011$ & $1870-2010$ & $1978-2010$ & $1978-2010$ \\
Portugal & $1870-1903 / 1920-2011$ & $1920-2011$ & $1979-2011$ & - \\
Sweden & $1871-2011$ & $1871-2011$ & $1871-2011$ & $1975-2011$ \\
United States & $1880-2011$ & $1896-2011$ & $1947-2011$ & $1947-2011$ \\
\hline \hline
\end{tabular}

Notes: The data cover commercial banks and other financial institutions such as savings banks, credit unions, and building societies. Data generally cover all monetary financial institutions. The following exceptions apply. Australia: pre-WWII mortgage loans are savings banks only; Belgium: pre-WWII mortgage loans are other financial institutions (OFIs) only; Canada: mortgage loans before 1954 are OFIs only; Switzerland: pre-1906 loans are commercial banks (CBs) only; Germany: pre-1920 mortgage loans are OFIs only; Spain: until 1996 total loans are CBs only; Denmark: pre-WWII mortgage loans are OFIs only; Japan: pre-WWII mortgage loans are CBs only; Norway: pre-1900 mortgage loans are mortgage banks only; Portugal: 1870-1903 total loans are CBs only; Sweden: pre-1975 household lending is mortgage lending only; USA: pre-1896 real estate lending is savings banks only. Sources listed in a forthcoming online data appendix. See text.

The new data confirm the long-run patterns that we uncovered in earlier work: after an initial period of financial deepening in the late 19th century the average level of the credit-to-GDP ratio in advanced economies reached a plateau of about 50\%-60\% around 1900. Subsequently, with the notable exception of the deep contraction seen in bank lending in the Great Depression and World War II, the ratio broadly remained in this range until the 1970s. The trend then broke: the three decades that followed were marked by a sharp increase in the volume of bank credit relative to GDP. Bank lending on average roughly doubled relative to GDP between 1980 and 2009 as average bank credit to GDP increased from $62 \%$ in 1980 to $118 \%$ in 2010. 
Figure 1: Bank credit to the domestic economy, 1870-2011, with a comparison of data from three different sources: Average ratio to GDP by year for 17 countries

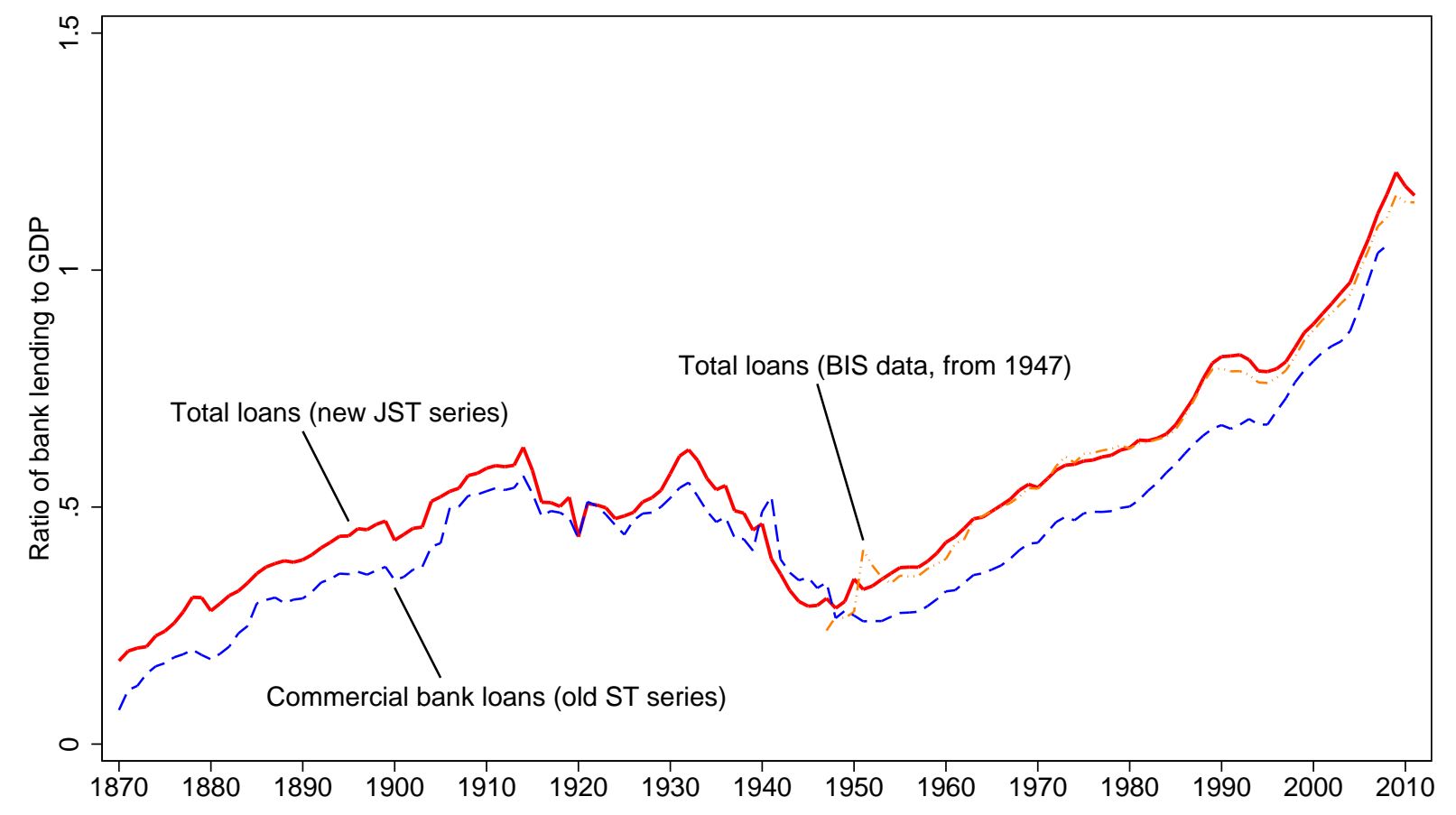

Notes: Total Loans (new JST series) refers to new data on total loans to the non-financial private sector (businesses and households) from the banking sector (broadly defined as explained in the text) and compiled by us for this paper; Commercial bank loans (old ST series) refers data on total loans to the nonfinancial private sector by commercial banks compiled by Schularick and Taylor (2012); Total loans (BIS data) refers to data on total loans by the banking sector compiled by the BIS (2013). All three series reported as a fraction to GDP and then averaged across all 17 countries in the sample. See text.

The data dramatically underscore the size of the credit boom prior to the global financial crisis of 2008. A substantial part of that boom occurred in a very short time span of little more than 1o years between the mid-1990s and 2008/9. For our 17 country sample, the average bank credit to GDP ratio rose from $79 \%$ of GDP in 1995 to $112 \%$ of GDP in 2007-an unprecedented increase of more than 30 percentage points (p.p.) as a ratio to GDP in just 12 years, implying a rapid pace of change of around 2.5 percentage points per year (p.p.y.). Moreover, this is only a lower bound estimate as it excludes credit creation by the shadow banking system, which was significant in some countries, such as in the U.S. and the U.K. 
Figure 2: Bank mortgage and non-mortgage lending to GDP, 1870-2011: Average ratio to GDP by year for 17 countries

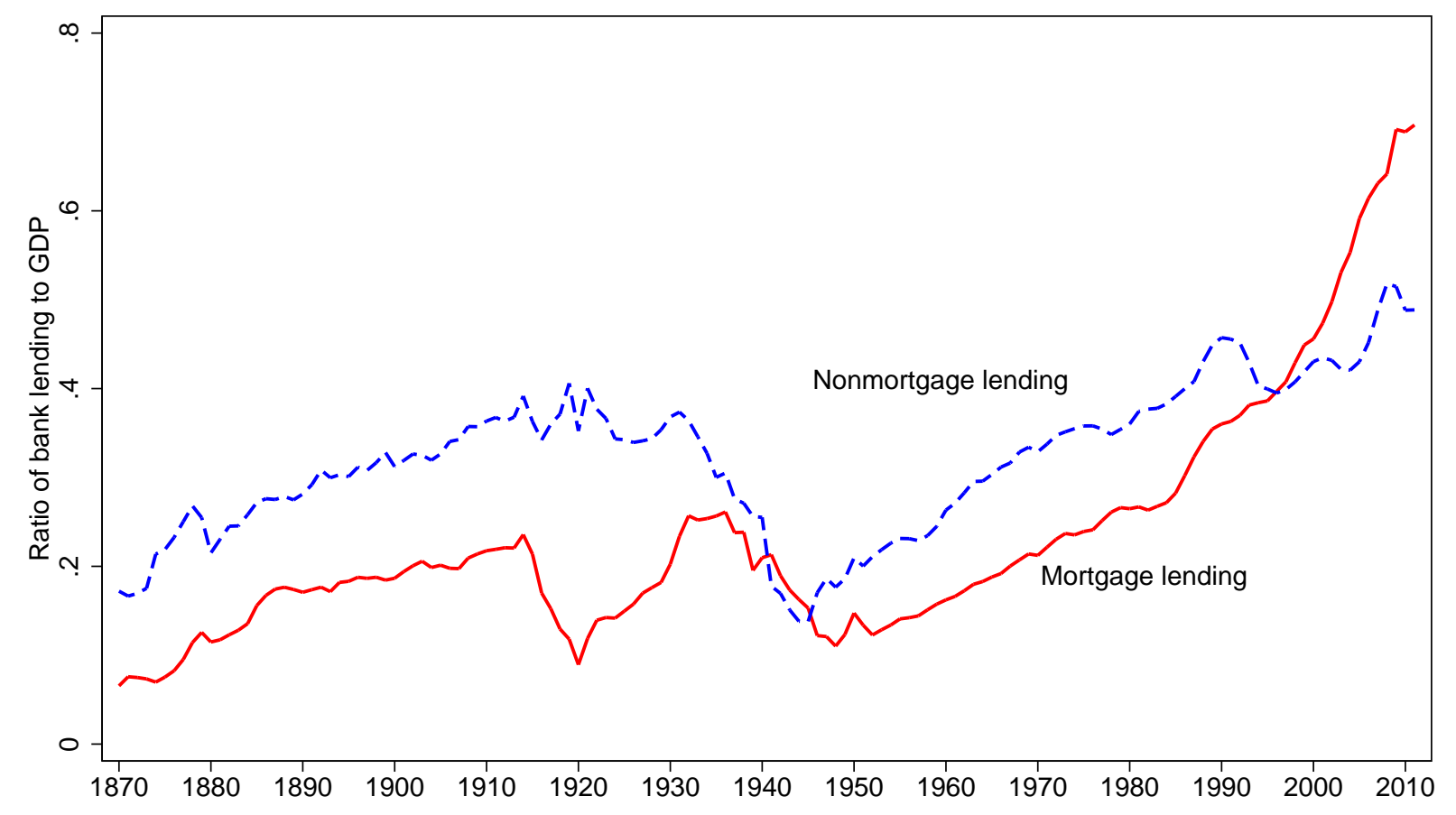

Notes: Mortgage (residential and commercial) and non-mortgage lending to the business and household sectors. Average across 17 countries. See text.

The next two sections explore the composition of this remarkable long-run leveraging of the advanced economies in more detail. We study the role of mortgage lending as well as changes in the sectoral composition of bank credit.

\section{The Great Mortgaging}

Figure 2 shows the long-run trends of mortgage credit and unsecured lending to business and household sectors since 1870 . The visual impression is striking. Over a period of 140 years the level of non-mortgage lending to GDP has risen by a factor of about 3, while mortgage lending to GDP has risen by a factor of 8 , with a big surge in the last 40 years.

Virtually the entire increase in the bank lending to GDP ratios in our sample of 17 advanced economies has been driven by the rapid rise in mortgage lending relative to output since the 1970s. Non-mortgage lending to business and consumers for purposes 
other than purchase of real estate has grown much more slowly and actually remained remarkably stable in the long run relative to output. On the eve of World War I, nonmortgage bank lending in the advanced economies was $41 \%$ as a ratio to GDP on average. In 2010 the corresponding ratio was $46 \%$, only marginally higher. Bank lending to GDP ratios have risen so strongly on average because of a parallel increase in mortgage credit: from an average of about $20 \%$ as a ratio to GDP at the beginning of the 2oth century to $69 \%$ of GDP by 2010.

It is important to stress that a substantial share of mortgage debt was held privately outside the banking system in the 19th century. Exact numbers are hard to estimate. In France and the U.K. privately held mortgage debt likely accounted for up to 10 percent of GDP around the year 1900; in the U.S. and Germany an even higher share of farm and non-farm mortgages was probably held outside banks (Hoffman, Postel-Vinay, and Rosenthal 2000). To some extent, the strong rise in mortgage lending relative to GDP evident in our data represents the integration of these earlier forms of "informal" private lending into the financial system in the course of the 2oth century.

Figure 3 gives a country-by-country snapshot of the composition of the loan books of the banking sector at three points in time: 1928, 1970, and 2007. This allows us to compare the business of banking on the eve of the Great Depression, right before the Bretton Woods System collapsed, and just before the global financial crisis of 2008. These three snapshots tell a consistent story. In most advanced countries, the share of mortgage lending relative to other lending has increased dramatically over the past century. With very few exceptions, the banks' primary business consisted of non-mortgage lending to companies both in 1928 and 1970. In 2007 banks in most countries had turned primarily into real estate lenders. On average, non-mortgage lending accounted for $73 \%$ of the total in 1928 and $65 \%$ in 1970. The share had fallen to less than $40 \%$ of total bank lending by 2007. In the U.S. and Norway, $68 \%$ of loans on bank balance sheets were mortgages in 2007 , in the U.K. the corresponding figure was $63 \%$. 
Figure 3: Three snapshots of the real estate share of bank lending: 1928, 1970, and 2007

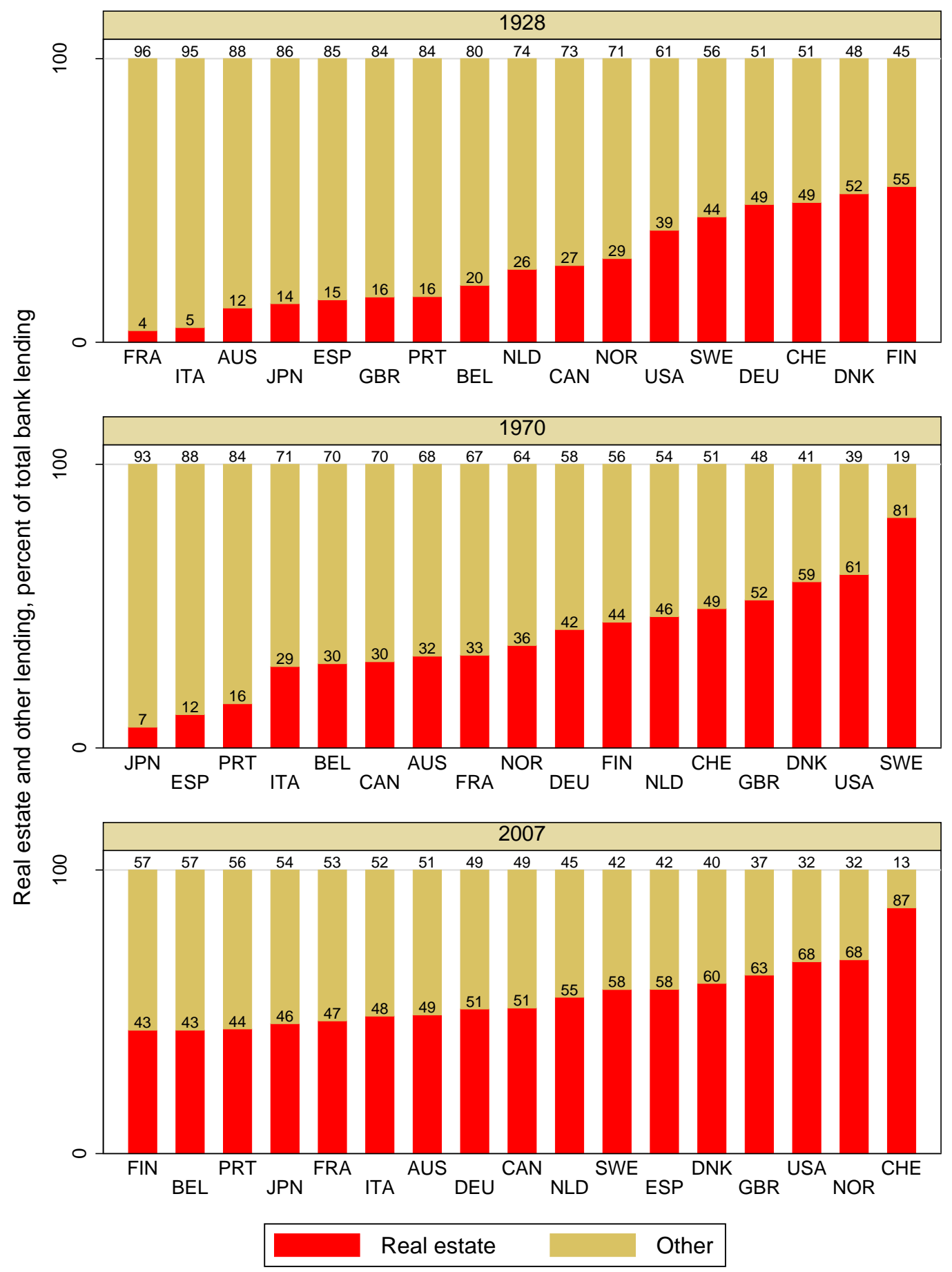

Notes: Share of mortgage lending to total lending in 1928, 1970, and 2007 for each of the countries in the sample. See text. 
Figure 4: Aggregate share of real estate lending in total bank lending

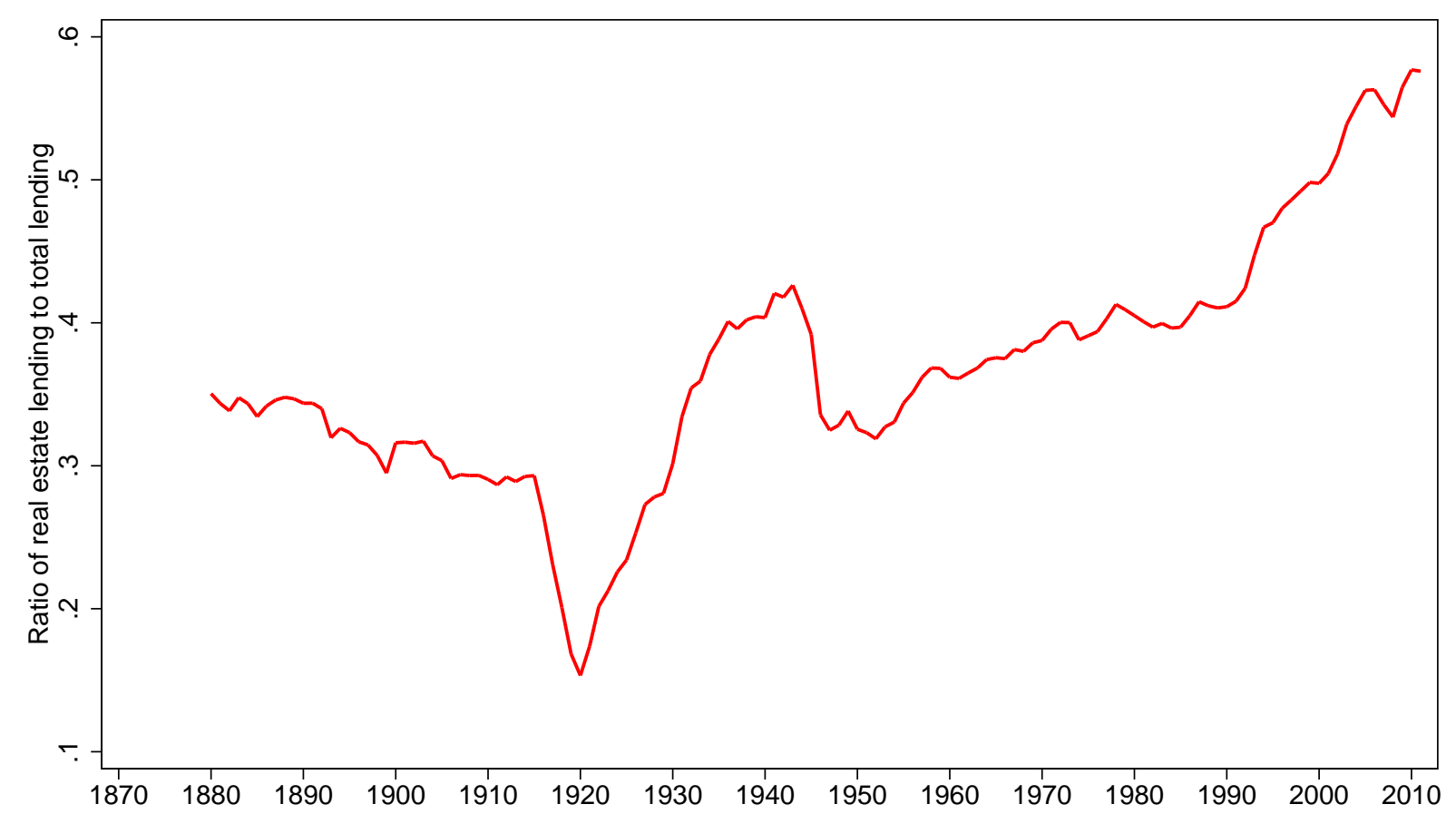

Notes: Share of real estate lending to total lending averaged across 17 countries. Before 1880 the sample size is too small for use. See text.

Figure 4 shows the time profile of this astonishing change in the business of banking, and tracks the share of real estate loans on banks' balance sheets since 1870 . We can clearly see the instability of credit in the interwar period when banks in many countries were forced to finance the war efforts of governments and cut back sharply on business lending in the 1930s. After WWII real estate credit increased as a share of total lending, driven in part by the reconstruction efforts in Europe and the boom in suburban housing in many countries, notably the United States. However, the overall share of real estate credit on banks' balance sheets remained around $40 \%$ until the mid-1980s, whereupon we see the start of a global real estate lending boom for the past 30 years leading to a large jump in the ratio. As a result, the shares of mortgage and non-mortgage lending are now approximately the inverse of what they were at the beginning of the 2oth century. 


\section{The Leveraging of Households}

In this section we examine sectoral trends in bank lending. Table 2 dissects the increase of total bank lending to GDP ratios over the past 50 years into growth of household debt and business debt. In the 50 years since 1960 we see that the increase in total lending to the private sector amounted to about 80 percentage points (p.p.) of GDP on average in the 17 advanced economies. At the country level, Spain tops the list with overall growth of the bank credit to GDP ratio of 135 p.p. followed closely by the Netherlands and Denmark.

Table 2: Change in bank lending to GDP ratios (multiple), 1960-2010

\begin{tabular}{lccccc}
\hline \hline Country & Total lending & Mortgage & Non-mortgage & Households & Business \\
\hline Spain & 1.35 & 0.97 & 0.38 & 0.75 & 0.60 \\
Netherlands & 1.34 & 0.69 & 0.65 & - & - \\
Denmark & 1.31 & 0.98 & 0.33 & 0.74 & 0.57 \\
Australia & 1.13 & 0.70 & 0.42 & 0.77 & 0.35 \\
Portugal & 1.07 & 0.60 & 0.47 & - & - \\
Great Britain & 0.89 & 0.74 & 0.16 & 0.72 & 0.17 \\
Sweden & 0.80 & 0.49 & 0.31 & - & - \\
USA* & 0.66 & 0.53 & 0.13 & 0.49 & 0.17 \\
USA & 0.10 & 0.07 & 0.03 & 0.03 & 0.07 \\
Canada & 0.65 & 0.35 & 0.30 & 0.54 & 0.10 \\
France & 0.61 & 0.41 & 0.21 & 0.45 & 0.17 \\
Finland & 0.61 & 0.26 & 0.35 & 0.43 & 0.19 \\
Belgium & 0.55 & 0.28 & 0.27 & 0.30 & 0.24 \\
Italy & 0.55 & 0.44 & 0.11 & 0.39 & 0.16 \\
Norway & 0.51 & 0.55 & -0.04 & - & - \\
Germany & 0.51 & 0.30 & 0.21 & 0.21 & 0.29 \\
Switzerland & 0.48 & 0.74 & -0.26 & 0.50 & -0.03 \\
Japan & 0.32 & 0.39 & -0.07 & 0.27 & 0.05 \\
\hline Average & 0.78 & 0.55 & 0.23 & 0.53 & 0.25 \\
Fraction of average & 1.00 & 0.71 & 0.29 & 0.68 & 0.32 \\
\hline Notes:Colut
\end{tabular}

Notes: Column (1) reports the change in the ratio of total lending to GDP expressed as a multiple of the initial value between 1960 to 2010 ordered from largest to smallest change. Columns (2) and (3) report the change due to real estate versus non-real estate lending. Columns (4) and (5) instead report the change due to lending to households versus lending to businesses. The USA entry with * includes credit market debt. Average reports the across country average for each column. Fraction of average reports the fraction of column (1) average explained by each category pair in columns (2) versus (3) and (4) versus (5). Notice that averages in columns (4) and (5) have been rescaled due to missing data so as to add up to total lending average reported in column (1). See text. 
At the bottom of the list we find Japan, Switzerland, and Germany. With regard to the sectoral composition, the picture could not be clearer. The increase in lending has been driven primarily by increased lending to the household sector. Household borrowing accounts for about $2 / 3$ of the total increase in bank credit since 1960, predominantly driven by real estate lending. But there are important differences between individual countries: Belgian, German, and Japanese households have increased their debt levels by 30 p.p. (or less) of GDP, while their Australian, Spanish, British, and Dutch counterparts have ramped up debt levels by about 75 p.p. of GDP over the same period.

A natural question to ask is whether this surge in household borrowing reflects rising asset values without substantial shifts in household leverage ratios (defined as the ratio of household mortgage debt to the value of residential real estate) or, on the contrary, whether households increased debt levels relative to asset values. The latter would potentially raise greater concerns about the macroeconomic stability risks stemming from more highly leveraged household portfolios.

We therefore gathered historical data for the total value of the residential housing stock (structures and land) for a number of benchmark years to relate household mortgage debt to asset values. We combine information from Goldsmith's (1985) seminal study of national balance sheets with the more recent and more precise estimates of historical wealth to income ratios by Piketty and Zucman (2013). There are considerable difficulties involved in the calculations so we restrict the analysis to a small sub-sample of countries for which we have long-run data. Yet even here the margins of error are likely to be big and the numbers should be interpreted with caution.3

Figure 5 shows that the ratio of household mortgage debt to the value of real estate has risen strongly in the United States and the United Kingdom in the past three decadesdespite the boom in house prices. In the United States mortgage debt to housing value

\footnotetext{
3In particular, it was not always possible to clearly separate the value of residential land from overall land for the earlier years and therefore we made assumptions on the basis of available data for certain benchmark years.
} 
Figure 5: Ratio of household mortgage lending to the value of the housing stock
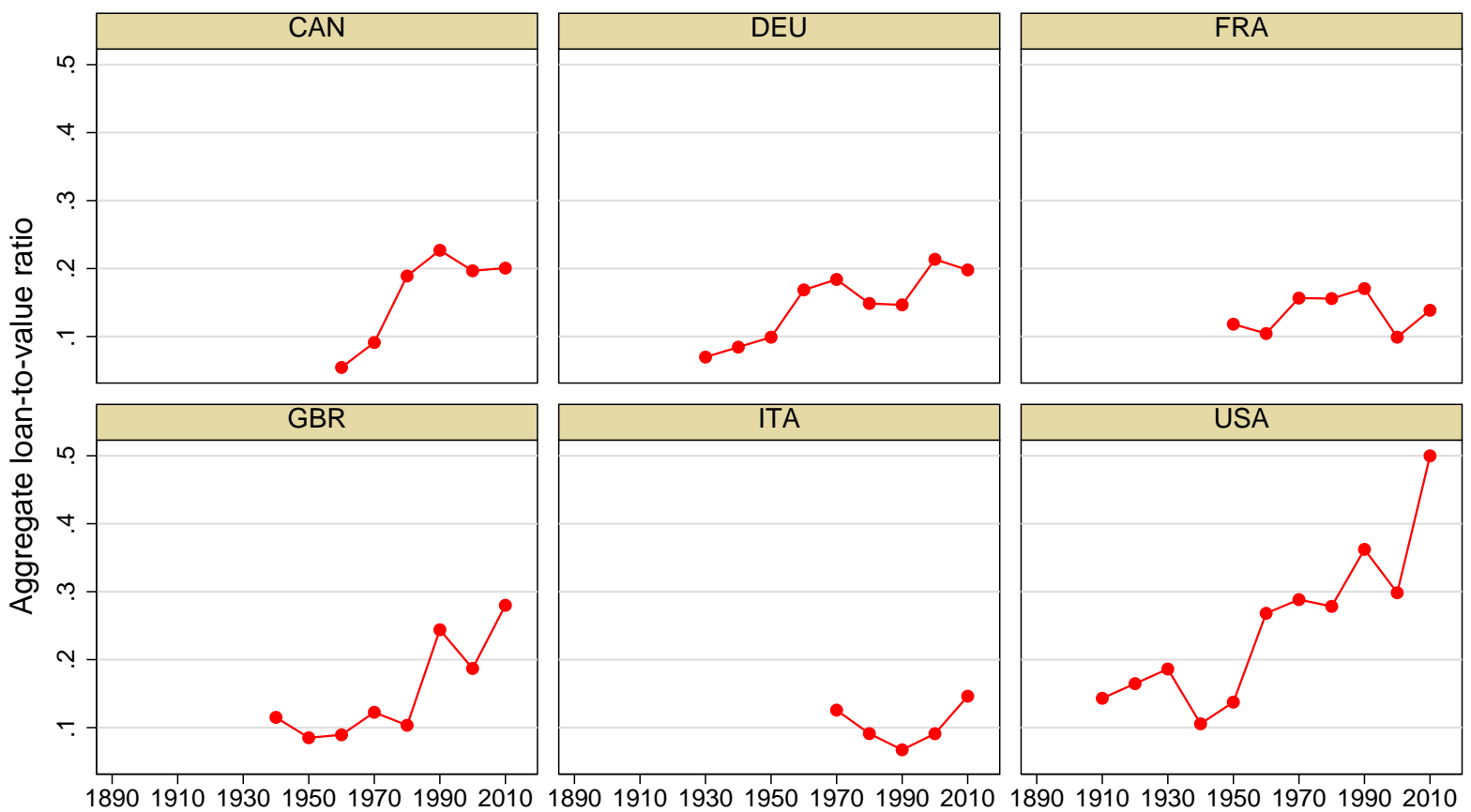

Sources: Piketty and Zucman (2013), Goldsmith (1985) and our data. Individual data points are rough approximations relying on reconstructed historical balance sheet data for benchmark years.

climbed from $28 \%$ in 1980 to over $40 \%$ in 2010 , and in the United Kingdom from slightly more than $10 \%$ to $28 \%$. A general upward trend in the second half of the 20 th century is also clearly discernible in a number of other countries.

\section{The Rise of Home Ownership}

The boom in mortgage lending and borrowing in the post-WWII era is a major trend that emerges from our data. Table 3 demonstrates that this rise in mortgage credit has financed a substantial expansion of home ownership in the advanced economies.

Home ownership rates were on average slightly above $40 \%$ around 1950 in the countries for which we have long-run data. In the $2000 \mathrm{~s}$ about $60 \%$ of households owned the house that they lived in-an increase of 20 percentage points in the course of the past half century. Put differently, while the notion that home ownership is a 
Table 3: Home ownership rates in the 2oth century (percent)

\begin{tabular}{lcccccccc}
\hline \hline & Canada & Germany & France & Italy & Switzerland & U.K. & U.S. & Average \\
\hline 1900 & & & & & & & 47 & \\
1910 & & & & & & & 46 & \\
1920 & & & & & & & 46 & \\
1930 & & & & & & 32 & 44 & \\
1940 & 57 & & & & & 32 & 47 & 43 \\
1950 & 66 & 39 & 38 & 40 & 37 & 42 & 62 & 46 \\
1960 & 66 & 34 & 41 & 45 & 34 & 50 & 63 & 48 \\
1970 & 60 & 36 & 45 & 50 & 29 & 58 & 64 & 51 \\
1980 & 63 & 39 & 47 & 59 & 30 & 68 & 64 & 55 \\
1990 & 63 & 39 & 55 & 67 & 31 & 69 & 67 & 60 \\
2000 & 66 & 45 & 56 & 80 & 35 & 69 & 60 \\
2010 & 69 & 45 & 58 & 82 & 37 & 64 & 65 & 60 \\
\hline \hline
\end{tabular}

Sources: Canada: Miron and Clayton (1987), "Housing in Canada 1945-1986"; Statistics Canada (2011), "Home ownership rates by age group, all households"; France: Friggit (2010), "Les ménages et leur logements depuis 1955 et 1970"; Germany: Statistisches Bundesamt (2011), "Statistisches Jahrbuch 2011"; Italy: Balchin (1996), "Housing Policy in Europe"; Dolinga and Elsinga (2013), "Demographic Change and Housing Wealth"; Switzerland: Werczberger (1997), "Home Ownership and Rent Control in Switzerland," Bundesamt für Wohnungswesen (2013), "Wohneigentums, 1950-2000"; United Kingdom: Office for National Statistics (2013), "A Century of Home Ownership and Renting in England and Wales"; United States: Census Bureau (2010), "Housing Characteristics."

constitutive part of the national identity may be a widely accepted idea in many countries, on closer inspection what is often described as a fundamental trait of national culture turns out to be a relatively recent phenomenon. In the U.K. for instance, home ownership rates were as low as $23 \%$ in the first quarter of the 20 th century. In the U.S. too, the majority of households did not own their homes until about 1960.

The rise of credit-financed home ownership in the second half of the 2oth century has clearly been aided by the growth in scale and scope of housing policy, albeit the exact contribution remains hard to quantify. Large scale interventions into housing markets were largely a product of the Great Depression, but remained an important part of the post-WWII policy landscape in many countries.

In the United States the National Housing Act of 1934 led to the creation of the Federal Housing Authority (FHA), whose primary purpose was to insure banks and other private lenders for home loans and to create a liquid secondary mortgage market. Two years 
before, in 1932, the Federal Home Loan Bank System had been established. Through its government backing, the System could borrow at favorable interest rates and pass them on to mortgage borrowers, an arrangement that became an enduring feature of the American housing finance system (Gaertner 2012). President Roosevelt created the Federal National Mortgage Association (FNMA) in 1938 which quickly became known by its nickname Fannie Mae. The agency issued bonds in capital markets with implicit backing from the federal government and invested in FHA insured mortgage loans, thereby creating a more liquid secondary market for insured mortgages. As time went by the standardization of loans using FHA criteria enabled nationwide banks and other financial institutions to move into geographically remote mortgage markets, and this translated into a rising share of mortgages on banks' balance sheets.

Government interventions in the U.S. housing markets intensified after WWII mainly due to the activities of the Veterans Administration (VA) which was established as part of the G.I. Bill in 1944. VA guaranteed loans had median loan-to-value ratios of $91 \%$, and a substantial proportion even passed the 100\% bar (Fetter 2013). The VA and FHA programs insured more than 6.5 million mortgages in the first fifteen years after the war and the associated rise of suburbia transformed the American landscape. The share of federally subsidized mortgage credit relative to all mortgages reached $40 \%$ in the 1950s. On its own, the G.I. Bill likely accounted for up to $25 \%$ of the increase in home ownership for the cohorts affected by the VA programs (Fetter 2013). Moreover, while the tax deduction of interest expenses had formed part of the U.S. tax code since the introduction of the federal income tax in 1913, the sharp rise in mortgage debt and highly progressive income tax rates turned the mortgage interest deduction into a much more important subsidy for home buyers in the postwar decades. Aided by such policies, American home ownership increased from $40 \%$ in the 1930 s to nearly $70 \%$ by 2005 before declining to $65 \%$ in the wake of the global financial crisis.

While the U.K. shares a similar experience, with home ownership rates rivaling those 
of the U.S., not all countries implemented changes in policies to boost private home ownership and mortgages. Germany and Switzerland provide good counterexamples. In Germany, loan-to-value ratios at savings and mortgage banks (the main providers of home loans) were often capped at $60 \%$. At the same time, the comparatively high levels of rent protection that were put in place in the immediate postwar years were upheld in the following decades and the German tax code provided only limited incentives to take on debt. Switzerland even levied taxes on the imputed rents of house owners. As a consequence, the home ownership rate in Germany stood at $43 \%$ in 2013 and was hence only marginally higher than the $39 \%$ ratio reached in 1950. In a similar fashion, home ownership in Switzerland stagnated around 35\% in the past half century.

In addition to country-specific housing policies, international banking regulation also contributed to the growing attractiveness of mortgage lending from the perspective of the banks. The Basel Committee on Bank Supervision (BCBS) was founded in 1974 in reaction to the collapse of Herstatt Bank in Germany. The Committee served as a forum to discuss international harmonization of international banking regulation. Its work led to the 1988 Basle Accord (Basel I) that introduced minimum capital requirements and, importantly, different risk weights for assets on banks' balance sheets. Loans secured by mortgages on residential properties only carried half the risk weight of loans to companies. This provided another incentive for banks to expand their mortgage business which could be run with higher leverage. As Figure 1 shows, a significant share of the global growth of mortgage lending occurred in recent years following the first Basel Accord.

\section{Mortgage Credit and Financial Instability}

We now turn from data description to formal statistical analysis, and our first hypothesis addresses a crucial question as to why one should care about the disaggregated credit measures that we have so laboriously collected. Namely, have changes in the structure of financial intermediation, highlighted by the growing importance of mortgages in total 
bank credit, made advanced economies more financially fragile?

In this section, we look at the classification ability of various credit-based measures in predictive models of financial stability. In particular, we are interested if and how the disaggregated credit data help improve the classification ability of crisis forecast models and whether housing credit today has become more closely associated with financial crisis risks as its share in total credit has grown.

Following Schularick and Taylor (2012) we start from a probabilistic model that specifies the log-odds ratio of a financial crisis occurring in country $i$ in year $t$, denoted with the binary variable $S_{i t}$, as a linear function of lagged credit ratios in year $t$,

$$
\log \frac{P\left[S_{i t}=1 \mid X_{i t}\right]}{P\left[S_{i t}=0 \mid X_{i t}\right]}=\psi_{0 i}+\psi_{1} X_{i t}+e_{i t}
$$

where $X_{i t}$ refers to a vector of lagged changes of the credit ratios of interest. Here we use 5-year moving averages as a parsimonious way to summarize medium-term fluctuations. Notice that the model includes country fixed-effects. We report estimates based on a variety of specifications detailed below, essentially a horse-race among the various credit aggregates using the full sample, the pre-WWII era, and the post-WWII period. The error term $e_{i t}$ is assumed to be well behaved.

Dates of systemic financial crises are taken from Jordà, Schularick, and Taylor (2013) with updates, which in turn builds on Bordo et al. (2001) and Reinhart and Rogoff (2009). The Laeven and Valencia $(2008,2012)$ dataset of systemic banking crises is the main source for post-1970 crisis events.4 Section A in the appendix provides the country-specific dates of financial crises that we use.

\footnotetext{
4Following the definition of Laeven and Valencia (2012), a financial crisis is characterized as a situation in which there are significant signs of financial distress and losses in wide parts of the financial system that lead to widespread insolvencies or significant policy interventions. The important distinction here is between isolated bank failures, such as the collapse of the Herstatt Bank in Germany in 1975 or the demise of Baring Brothers in the U.K. in 1995, and system-wide distress as it occurred, for instance, in the crises of the 1890 and the 1930s, in the Japanese banking crises in the 1990s, or during the global financial crisis of 2008. It is clear that the lines are not always easy to draw, but the overall results appear robust to variations in the crisis definitions.
} 
The key results are shown in Table 4 Column (1) reports the null model with countryfixed effects only. This serves as a benchmark or null to judge whether a more elaborate model is any better at explaining the data. Next we consider the models based on mortgage loans in column (2) and non-mortgage loans in column (3), as well as the combination of both (4). Panel (a) reports the results for the full sample from 1870 to 2011 (excluding world wars), panel (b) is based on a pre-WWII sample from 1870 to 1939 (excluding WWI) with corresponding results reported in columns (5) to (8), and panel (c) is based on a post-WWII sample from 1946 to 2011 with corresponding results reported in columns (9) to (12).

Earlier work by Schularick and Taylor (2012) showed that, in aggregate, credit helps predict financial crises. But with our new dataset we can ask a sharper question: does the type of credit that drives the expansion make a difference? We confirm that a high rate of credit extension over the previous five years is indicative of an increasing risk of a financial crisis. This is true for both mortgage lending and non-mortgage lending (columns 2-4). All forms of credit growth over GDP have highly significant coefficient estimates. Over the long-run, there does not appear to be only one type of credit-boom driven financial instability. Financial fragility seems to have a variety of sources.

However, the type of credit does seem to matter, and we find evidence that the changing nature of financial intermediation has shifted the locus of crisis risks increasingly toward real estate lending cycles. Whereas in the pre-WWII period mortgage lending is not statistically significant, either individually or when used jointly with unsecured credit (columns 6 and 8 ), it becomes highly significant as a crisis predictor in the post-WWII period (see columns 10 and 12). Nevertheless, both types of credit appear to play an independent role as column (12) shows.

A different way to see this changing relationship is through the AUC statistic.5 The

${ }^{5}$ AUC stands for Area Under the Curve The curve is usually the receiver operating characteristic curve or ROC. In Jordà and Taylor (2011) it refers to the Correct Classification Frontier or CCF. Jordà and Taylor (2011) provide an overview of this literature and the AUC, ROC, and CCF. 
Table 4: Classifying financial crises: logit prediction models

\begin{tabular}{|c|c|c|c|c|}
\hline (a) Full sample & (1) & (2) & (3) & (4) \\
\hline Mortgage loans & & $\begin{array}{c}25 \cdot 77^{* * *} \\
(7 \cdot 73)\end{array}$ & & $\begin{array}{c}14.80^{*} \\
(8.97)\end{array}$ \\
\hline Non-mortgage loans & & & $\begin{array}{c}47.00^{* * *} \\
(10.36)\end{array}$ & $\begin{array}{c}41.69^{* * *} \\
(10.93)\end{array}$ \\
\hline AUC & $\begin{array}{c}0.61 \\
(0.03)\end{array}$ & $\begin{array}{c}0.67 \\
(0.03)\end{array}$ & $\begin{array}{c}0.72 \\
(0.03)\end{array}$ & $\begin{array}{c}0.73 \\
(0.03)\end{array}$ \\
\hline Observations & 2040 & 1746 & 1716 & 1716 \\
\hline (b) Pre-WWII & (5) & (6) & (7) & $(8)$ \\
\hline Mortgage loans & & $\begin{array}{c}18.76 \\
(12.65)\end{array}$ & & $\begin{array}{c}23.38 \\
(20.66)\end{array}$ \\
\hline Non-mortgage loans & & & $\begin{array}{c}66.91^{* * *} \\
(21.57)\end{array}$ & $\begin{array}{c}66.27^{* * *} \\
(20.96)\end{array}$ \\
\hline AUC & $\begin{array}{c}0.63 \\
(0.04)\end{array}$ & $\begin{array}{c}0.69 \\
(0.04)\end{array}$ & $\begin{array}{c}0.77 \\
(0.04)\end{array}$ & $\begin{array}{c}0.78 \\
(0.04)\end{array}$ \\
\hline Observations & 1003 & 721 & 691 & 691 \\
\hline (c) Post-WWII & (9) & (10) & $(11)$ & $(12)$ \\
\hline Mortgage loans & & $\begin{array}{c}45.94^{* * *} \\
(13.67)\end{array}$ & & $\begin{array}{l}33.11^{* *} \\
(13.93)\end{array}$ \\
\hline Non-mortgage loans & & & $\begin{array}{c}50.06^{* * *} \\
(14 \cdot 39)\end{array}$ & $\begin{array}{l}35 \cdot 70^{* *} \\
(15 \cdot 57)\end{array}$ \\
\hline AUC & $\begin{array}{c}0.62 \\
(0.05)\end{array}$ & $\begin{array}{c}0.72 \\
(0.05)\end{array}$ & $\begin{array}{c}0.72 \\
(0.06)\end{array}$ & $\begin{array}{c}0.75 \\
(0.05)\end{array}$ \\
\hline Observations & 976 & 964 & 964 & 964 \\
\hline \multicolumn{5}{|c|}{$\begin{array}{l}\text { Notes: }{ }^{* * *} p<0.01,{ }^{* *} p<0.05,{ }^{*} p<0.10 \text {. Robust standard errors for the regression coefficients in } \\
\text { parentheses. Country fixed effects not shown. The two world wars are excluded from the estimation sample. } \\
\text { Panel (a) uses the full sample from } 1870 \text { to } 2010 \text { across the } 17 \text { countries. Panel (b) uses pre-WWII data only. } \\
\text { Panel (c) uses post-WWII data only. The reference null model based on a specification with country fixed } \\
\text { effects only reported in columns (1), (5) and (9). Non-mortgage loans has an AUC significantly different } \\
\text { from the null model in all } 3 \text { samples. Mortgage loans has an AUC that is not statistically different from the } \\
\text { null model in the pre-WWII sample but is significant in the post-WWII and in the full samples. Standard } \\
\text { errors for the AUC in parentheses. See text. }\end{array}$} \\
\hline
\end{tabular}


AUC is a summary statistic of classification ability whose asymptotic distribution is Gaussian in large samples, making inference straightforward (see Jordà and Taylor 2011). In the simplest models the AUC takes on the value of $I$ for perfect classification ability and 0.5 for an uninformative classifier or "coin toss." In our application we replace the 0.5 null with the AUC from the model with fixed-effects only 6 With the AUC we can then compare the classification ability of models using different sub-categories of credit.

The AUC tests for predictive ability for the different models lend support to the view that over time mortgage credit has come to play a larger role in the genesis of financial instability. In panel (b) the predictive ability of the mortgage based model is far inferior to the non-mortgage or combined model before 1940: compare column (6) with columns (7) and (8). But in panel (c) for the post-WWII period the AUC is a solid 0.72 , considerably higher than before and as good as the AUC of the non-mortgage based model: see columns (10) and (11). Here the mortgage credit based crisis prediction model outperforms the null model by a good margin: the fixed effects null AUC is 0.62, as reported in column (9). Moreover, it is almost on par with the combined model in column (12) and performs similarly in terms of overall classification ability to the model using non-mortgage loans only as reported in column (11), with these results contrasting with the findings for the pre-WWII era.

\section{Mortgage Booms, Financial Crises, and Their Aftermath}

The second half of the twentieth century saw an unprecedented increase in aggregate credit volumes. As we saw in Figure 1 , total bank lending as a ratio to GDP more than doubled relative to the first half of the 2oth century. Using our new dataset we were able to show that this striking trend was in large part driven by the tripling of real estate lending, in particular mortgage lending to households, as shown in Figure 2 . On the eve

\footnotetext{
${ }^{6}$ Some countries have been more prone to financial crises than others historically. We want to examine the marginal contribution of the credit variables beyond differences in country-average crisis incidence.
} 
of the 2008 global financial crisis real estate loans represented about two thirds of all bank lending in the U.S. and most other advanced economies. As a close correlate of this trend we saw that mortgage credit became a specific source of financial instability in advanced economies in the post-WWII era, as discussed in the previous section.

We now turn to the aftermath of lending booms and study their consequences for the real economy. The objective is to see if and how the important shifts in the structure of financial intermediation have implications for the role of credit over the business cycle: is there historical evidence that recessions are more severe if they are preceded by lending booms? Is the much-debated debt overhang phenomenon a regular feature of the modern business cycle? Our analysis will be based on the near-universe of business cycles in advanced economies since 1870 .

Debt overhang and the consequences of deleveraging have been a central focus of recent work on macrofinancial linkages. Many studies have pointed to debt overhang as a potential cause for slow recoveries from financial crises (see for example Cerra and Saxena 2008; Reinhart and Rogoff 2009; Mian and Sufi 2010, 2014; Jordà, Schularick, and Taylor 2011, 2013). Our analysis goes beyond previous attempts at measuring the effects of debt overhang in two important ways. First, we use the new disaggregated credit dataset to study potentially unknown linkages between specific forms of bank credit and the real economy as well as potential shifts in these relationships over time. Second, we apply novel econometric techniques that allow us to address concerns often raised about the endogeneity of financial crises, and hence quantify more precisely the effects of debt overhang using a potential outcomes approach based on the Neyman-Rubin causal model.

We begin with as brief an exposition of the novel econometric approach we use as is possible and then move quickly on to the analysis. The following section characterizes the typical path of economies through recessions and recoveries in the near-universe of business cycles in advanced economies since 1870 using the Bry-Boschan algorithm to 
Table 5: Summary statistics for recession type indicators and credit measures

\begin{tabular}{lcccccc}
\hline \hline & \multicolumn{2}{c}{$(1)$} & \multicolumn{2}{c}{$(2)$} & \multicolumn{2}{c}{$(3)$} \\
& \multicolumn{2}{c}{ All } & \multicolumn{2}{c}{ Pre-WWII } & \multicolumn{2}{c}{ Post-WWII } \\
& Recessions & \multicolumn{2}{c}{ Recessions } & \multicolumn{2}{c}{ Recessions } \\
& mean & s.d. & mean & s.d. & mean & s.d. \\
\hline Normal recession (indicator) & 0.74 & $(0.44)$ & 0.74 & $(0.44)$ & 0.75 & $(0.44)$ \\
Financial crisis recession (indicator) & 0.26 & $(0.44)$ & 0.26 & $(0.44)$ & 0.25 & $(0.44)$ \\
\hline Total credit (p.p.y.) & 0.83 & $(2.39)$ & 0.52 & $(2.50)$ & 1.19 & $(2.22)$ \\
Mortgage credit (p.p.y.) & 0.63 & $(1.23)$ & 0.49 & $(1.14)$ & 0.79 & $(1.31)$ \\
Non-mortgage credit (p.p.y.) & 0.20 & $(1.96)$ & 0.03 & $(2.33)$ & 0.40 & $(1.39)$ \\
\hline Observations & 199 & & 108 & & 91 & \\
\hline \hline
\end{tabular}

Notes: Full sample: 1870 to 2010 for 17 countries. Excludes world wars. Normal recession refers to a binary indicator that is 1 for normal recession o otherwise. Financial crisis recession is a binary indicator that is the complement to the normal recession binary indicator just described. Private credit refers to the accumulated growth in total lending in the expansion as a fraction of GDP and reported as an annual rate in deviation from country specific means, in percentage points per year (p.p.y.). Mortgage credit and Non-mortgage credit are constructed in a similar way. Total lending is the sum of mortgage lending and non mortgage lending. See text.

demarcate peaks and troughs of economic activity. Having established the typical path of economies over the cycle, we ask if and how financial factors modulate this trajectory. We will look both at the (new) aggregate and the disaggregated credit series, thereby both corroborating and extending previous studies of debt overhang and deleveraging.

Table 5 synthesizes the salient features of the underlying data. Column (1) reports summary statistics for all cycles between 1870 and 2010, 199 in total; column (2) for cycles between 1870 and 1939, 108 in total; and column (3) for cycles between 1948 to 2010, 91 in total. Moreover, we differentiate between normal business cycles and those associated with financial crises. Recessions are hence sorted into normal recessions and financial crisis recessions. A financial crisis recession occurs when a financial crisis is observed within \pm 2 years of the business cycle peak. Section $B$ in the appendix contains a table detailing the breakdown into these two cases for our dataset.

We will now use this classification of the types of recessions to study if and how debt overhang worsens the path of economies through recession and recovery in normal times and after financial crises. We will also pay due attention to the possible endogeneity of 
financial crisis cycles using propensity score weights in the following section.

\subsection{Statistical Design}

The question that we ultimately want to answer is if and how financial factors influence the severity of normal and financial recessions. In this section we describe in greater detail our statistical approach. Compared to previous literature the key methodological innovation will be to account for the possibility that financial crises are endogenous to the credit cycle. We will first establish that financial crisis recessions are indeed more severe than normal recessions and then move on to study if prior credit booms make either type of recession worse.

We are interested in the cumulative change in log real GDP per capita, $y$, from today to some future period $h$ measured in percentage points. We denote this cumulative change as $\Delta_{h} y_{\tau+h}$. The notation $\tau=t(p)$ indicates the calendar period $t$ associated with the $p^{t h}$ peak (or start of the recession) 7 In addition, let $d_{\tau}$ be an indicator variable that takes the value of one if the $p^{\text {th }}$ recession is associated with a financial crisis, and is zero otherwise.

The average path of normal versus financial crisis recessions can then be characterized as follows:

$$
\theta_{n}^{h}=\frac{1}{N_{h}} \sum_{d_{\tau}=0} \Delta_{h} y_{\tau+h} ; \quad \theta_{f}^{h}=\frac{1}{N_{f}} \sum_{d_{\tau}=1} \Delta_{h} y_{\tau+h} \quad \text { for } h=0,1, \ldots, H ，
$$

where $N_{n}$ and $N_{f}$ refer to the appropriate number of observations in each case ( $n$ is for normal recessions, $f$ is for financial crisis recessions). A plot of $\left\{\hat{\theta}_{n}^{h}\right\}_{h=0}^{H}$ represents the average path of the economy in normal recessions whereas the plot of the $\left\{\hat{\theta}_{f}^{h}\right\}_{h=0}^{H}$ represents the average path of the economy in financial crisis recessions instead. This is the type of plot that often appears in the literature, for example in Cerra and Saxena (2008) and Reinhart and Rogoff (2009). Any differences between the two paths, $\hat{\theta}_{n}^{h}$ and

7The country index is omitted to facilitate the exposition although in the applications below we include fixed effects and use cluster robust standard errors. These are among the main considerations given to the panel-data structure of our problem. 
$\hat{\theta}_{f}^{h}$, could be due to differences in observable characteristics between the two types, not necessarily because financial crises make the recession worse through an independent channel. The next step is therefore to ask whether financial crisis recessions are different from normal recessions, all else equal.

This is where synthetic control methods come in. Building on a large literature in biostatistics and more recently in econometrics, Angrist, Jordà, and Kuersteiner (2013) propose an inverse probability weighted (IPW) estimator of expression (2). The estimator consists of two stages. In the first stage, a model is constructed to determine the probability that the recession is of a financial crisis type $p\left(d_{\tau}=1 \mid\left\{Y_{\tau-l}\right\}_{l=0}^{L}\right)$. Here $Y_{\tau}$ denotes a vector of lagged observable macroeconomic controls observed up to $L$ periods before the recession starts. This probability will be called the propensity score and we denote its estimate as $\hat{p}_{\tau}$. The propensity score model can be estimated using a logit or a probit estimator, for example.

The second stage consists of recalculating expression (2) using weights given by the inverse of the propensity score in each bin. Weighting by the inverse of the propensity score puts more weight on those observations that were difficult to predict. These observations come closest to the random allocation ideal and hence receive more weight than those instances in which the type of recession was endogenous due to the other factors. Because it compensates for unknown nonlinearities, the inverse probability weighting can be seen as a more flexible mechanism to control for the role of observables compared to controlling only through the conditional mean. The difference between the path of the economy in financial crisis versus normal recessions then provides a measure of the average effect of the financial crisis on the path of the economy. It is calculated as

$$
\Lambda^{h}=\sum_{d_{\tau}=1} \frac{\Delta_{h} y_{\tau+h}}{\hat{p}_{\tau}}-\sum_{d_{\tau}=0} \frac{\Delta_{h} y_{\tau+h}}{1-\hat{p}_{\tau}}
$$


Alternatively, we know that expression (2) can be recast as a simple regression estimate

$$
\Delta_{h} y_{\tau+h}=\theta_{n}^{h}+\Lambda^{h} d_{\tau}+\epsilon_{\tau+h}
$$

Hence the counterparts to $\hat{\theta}_{n}^{h}$ and $\hat{\theta}_{f}^{h}$ in expression (2) can be directly obtained by noting that $\hat{\theta}_{f}^{h}=\hat{\theta}_{n}^{h}+\hat{\Lambda}^{h}$. In order to implement IPW in expression 3 all that is needed is to estimate expression (4) using weighted least-squares (WLS) with weights defined by $w_{\tau}=d_{\tau} / \hat{p}_{\tau}+\left(1-d_{\tau}\right) /\left(1-\hat{p}_{\tau}\right)$.

A natural extension to expression (4) is to include controls $\left\{Y_{\tau-l}\right\}_{l=0}^{L}$ directly in the regression estimator as well, such as in Jordà and Taylor (2013). We call this estimator IPWRA for "IPW regression adjusted" to follow the nomenclature used in this literature. The WLS estimation of this extended regression is an example of a "doubly robust" method (e.g. Lunceford and Davidian 2004; Wooldridge 2010; Glynn and Quinn 2010). The doubly robust moniker refers to the control for observables via two channels: directly in the regression mean and through the propensity score. Hence, only one of these two channels need be properly specified to produce consistent estimates.

Yet our key objective is to determine how aggregate credit and its disaggregated components affect the path of the recession. The doubly robust version of expression (4) estimated by WLS provides a natural springboard from which to do this. For example, let $\left(x_{\tau}-\bar{x}\right)$ denote a measure of credit accumulated in the expansion measured at annual rate in percentage points per year (p.p.y.) and in deviations from its historical mean (in the applications below, the mean is country specific). The effect of this variable on the path of the recovery can be measured using the following specification:

$$
\Delta_{h} y_{\tau+h}=\theta_{n}^{h}+\Lambda^{h} d_{\tau}+\beta^{h}\left(x_{\tau}-\bar{x}\right)+\sum_{l=0}^{L} Y_{\tau-l} \Gamma_{l}^{h}+\epsilon_{\tau+h} .
$$

Expression (5) is the standard specification of a local projection (Jordà 2005) with the $\left\{\hat{\beta}^{h} \times \delta\right\}_{h=0}^{H}$ as the estimate of the response of $\Delta_{h} y_{\tau+h}$ due to a perturbation in $x_{\tau}$ away 
from its mean $\bar{x}$ by an amount $\delta$. When expression (5) is estimated by WLS using the propensity score model for $\hat{p}_{\tau}$ and the associated weights $w_{\tau}$ we have a doubly robust estimate (given observable controls).

It is important to be clear about what the propensity score achieves in the calculation of this impulse response. The IPWRA ensures that endogeneity of financial crisis recessions is addressed as best as possible given the data that we have. Otherwise, estimates of the effects of experiments concerning $\left(x_{\tau}-\bar{x}\right)$ could be polluted by this endogeneity. In the analysis that follows $\left(x_{\tau}-\bar{x}\right)$ will refer to different measures of credit buildup during the expansion.

\subsection{Normal and Financial Recessions}

This section provides baseline estimates of the simple average paths in normal and financial recessions using WLS in expression (4) using IPW. In the subsequent sections we gradually incorporate the effect of alternative definitions of credit accumulation during the expansion and its components based on expression (5) using IPWRA, that is, estimated by WLS using the propensity score weights $w_{\tau}$. At each stage we provide the details of how these expressions are specifically implemented.

The set of controls $Y_{\tau-l}$ includes several important macroeconomic indicators: (1) the growth rate of real GDP per capita; (2) the growth rate of real loans per capita; (3) the CPI inflation rate; (4) the growth rate of real investment per capita; (5) short-term interest rates on government securities (usually 3 months or less in maturity); (6) long-term interest rates on government securities (usually 5 years or more in maturity); and (7) the current account to GDP ratio.

The propensity score model is estimated over the sample of recession-year events where we predict the normal versus financial-crisis type of the recession $d_{\tau}$ using two lags of this set of controls $Y_{\tau-l}$, country fixed effects, and the credit buildup indicator $\left(x_{\tau}-\bar{x}\right)$. This variable measures the annual change of total lending in the previous expansion as 
Figure 6: Checking for overlap in the propensity score

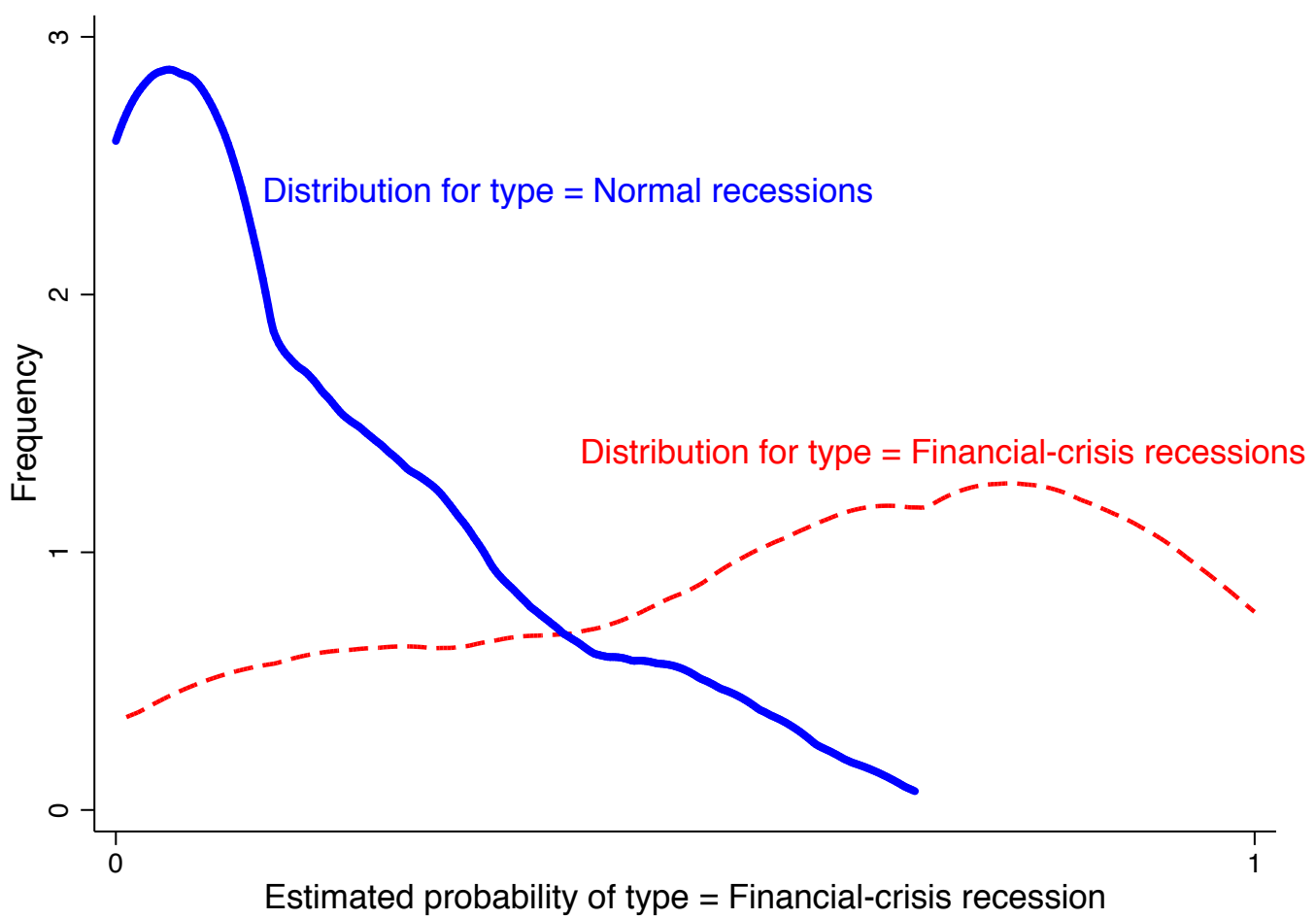

Notes: Propensity score logit models are estimated over the 1870-1939 (excluding WWI), and 1948-2010 samples. See text. The figure plots the empirical density of the predicted probabilities of Financial-crisis type recessions from the logit model where $d_{\tau}=1$ for Financial-crisis recessions and $d_{\tau}=0$ for normal recessions.

a ratio to GDP (in percentage points per year, or p.p.y.) to normalize differences in the duration of expansions. We estimate the propensity score using a logit model across the separate pre-WWII and post-WWII samples. WWII is a natural breakpoint given the trends in mortgage lending and overall credit discussed in previous sections.

Figure 6 displays the empirical density function of the predicted probabilities from the logit model of the propensity score. The figure shows that the logit model does not perfectly predict these binary outcomes and as a result there is a substantial region of overlap. Identification of the effects we seek comes from this overlap region.

Table 6 reports the results. Our initial estimates focused on three samples: all recessions (excluding world wars); recessions in the pre-WWII era; and recessions postWWII. Since we found no qualitative differences across these regimes only the full sample 
Table 6: Local projections: path of real GDP per capita in normal vs. financial recessions using inverse propensity-score weighting (IPW)

\begin{tabular}{lccccc}
\hline \hline Sample = All Recessions & Year 1 & Year 2 & Year 3 & Year 4 & Year 5 \\
\hline Normal recession & $-1.68^{* * *}$ & -0.06 & $1.92^{* * *}$ & $3.33^{* * *}$ & $5.04^{* * *}$ \\
& $(0.24)$ & $(0.41)$ & $(0.48)$ & $(0.52)$ & $(0.45)$ \\
Financial recession & $-2.52^{* * *}$ & $-3.42^{* * *}$ & $-2.73^{* * *}$ & $-1.60^{* *}$ & -0.78 \\
& $(0.36)$ & $(0.63)$ & $(0.74)$ & $(0.70)$ & $(0.60)$ \\
\hline$R^{2}$ & 0.630 & 0.416 & 0.416 & 0.403 & 0.527 \\
$H_{0}:$ Normal $=$ Financial; $p$-value & 0.16 & 0.00 & 0.00 & 0.00 & 0.00 \\
Observations & 150 & 150 & 150 & 150 & 150 \\
\hline \hline
\end{tabular}

Notes: ${ }^{* * *} \mathrm{p}<0.01,{ }^{* *} \mathrm{p}<0.05,{ }^{*} \mathrm{p}<0.1$. Robust standard errors in parentheses. Country fixed effects not shown. Full sample: 1870 to 2010. Excludes world wars. The table compares the conditional average path of a normal recession against that of a financial crisis recession. Each panel tests equality of the conditional mean in normal and financial crisis recessions by reporting the $p$-value of the test. The variables are weighted by the inverse propensity score for the probability of observing a financial crisis recession instead of a normal recession. See text.

results are reported (the subperiod results are shown in the appendix). For each horizon denoted Year 1 through Year 5, we report the estimates of the coefficients $\theta_{n}^{h}$ and $\theta_{f}^{h}$ using expression (4) along with a test of the null that, at each horizon, the coefficients are statistically equal to each other. In addition to the $p$-value of this test we also report robust standard errors (clustered by country). The results show that the null is easily rejected except in Year 1. The effects are quantitatively large. Conditional on controls, the gap between normal and financial crisis recession paths is about 1 percent of per capita real GDP (relative to the start of the recession) in Year 1, which then rises to 3.5 percent in Year 2, and persists at about 5 to 6 percent in Years 3, 4, and 5. The cumulated gap therefore amount to about 20 percent of annual output over the 5 years. The typical paths of economies in normal versus financial crisis recessions are clearly not the same.

\subsection{The Aftermath of Credit Booms}

Financial crises are different from normal recessions and this difference cannot be explained by a large set of observable macroeconomic aggregates. The IPW estimates reported in the previous section ensure that the conditioning set is entered in as flexible 
yet parsimonious a manner as possible. The question we ask in this section is whether the differences documented in the previous section are due to credit buildups in the prior expansion phase of the business cycle. Because we have shown that credit buildups are predictive of financial crises, we want to avoid the problem of having our measures of the response to credit reflect simply an endogenous response to the selection of recession events into the normal or financial type. We employ the IPWRA estimator introduced earlier for this reason.

Using the IPWRA estimator in expression (5) we build on Table 6 and extend the specification to include credit dynamics. Recall the credit variable $\left(x_{\tau}-\bar{x}\right)$ in expression (5) measures the annual change of total lending in the previous expansion as a ratio to GDP (in percentage points per year, or p.p.y.). We remove country-specific means to normalize differences across countries.

As an illustration, the scatter plot of Figure 7 shows the effect of the inverse probability weighting in the calculation of the $\beta^{h}$ that we report in Table 7. Figure 7 plots a partial scatter of the accumulated change in real GDP per capita in year 5 after the recession starts, against the credit variable $\left(x_{\tau}-\bar{x}\right)$ that we just described and which is observed at the start of the recession.

The inverse probability weighting, shown by the differences in the size of the points in the scatter plot, is an attempt to re-randomize the allocation of economies into the normal versus financial crisis recession bins. The largest weights of the subpopulation of economies that experienced a Financial crisis recession (shown in solid red) are associated with smaller credit booms. These are the financial crisis recessions that look more similar to the normal recessions. Conversely, economies that experienced a normal recession and a large credit buildup also receive larger weights because the are the closest counterpoint to economies that experienced a financial crisis. The weighting is somewhat more sophisticated than this simple explanation would indicate since there are cases in which macroeconomic fundamentals clearly predict that a financial crisis is likely even when 
Figure 7: Inverse probability weighted scatter plot of the accumulated deviations in real GDP per capita over 1-5 years into the recession against the credit measure

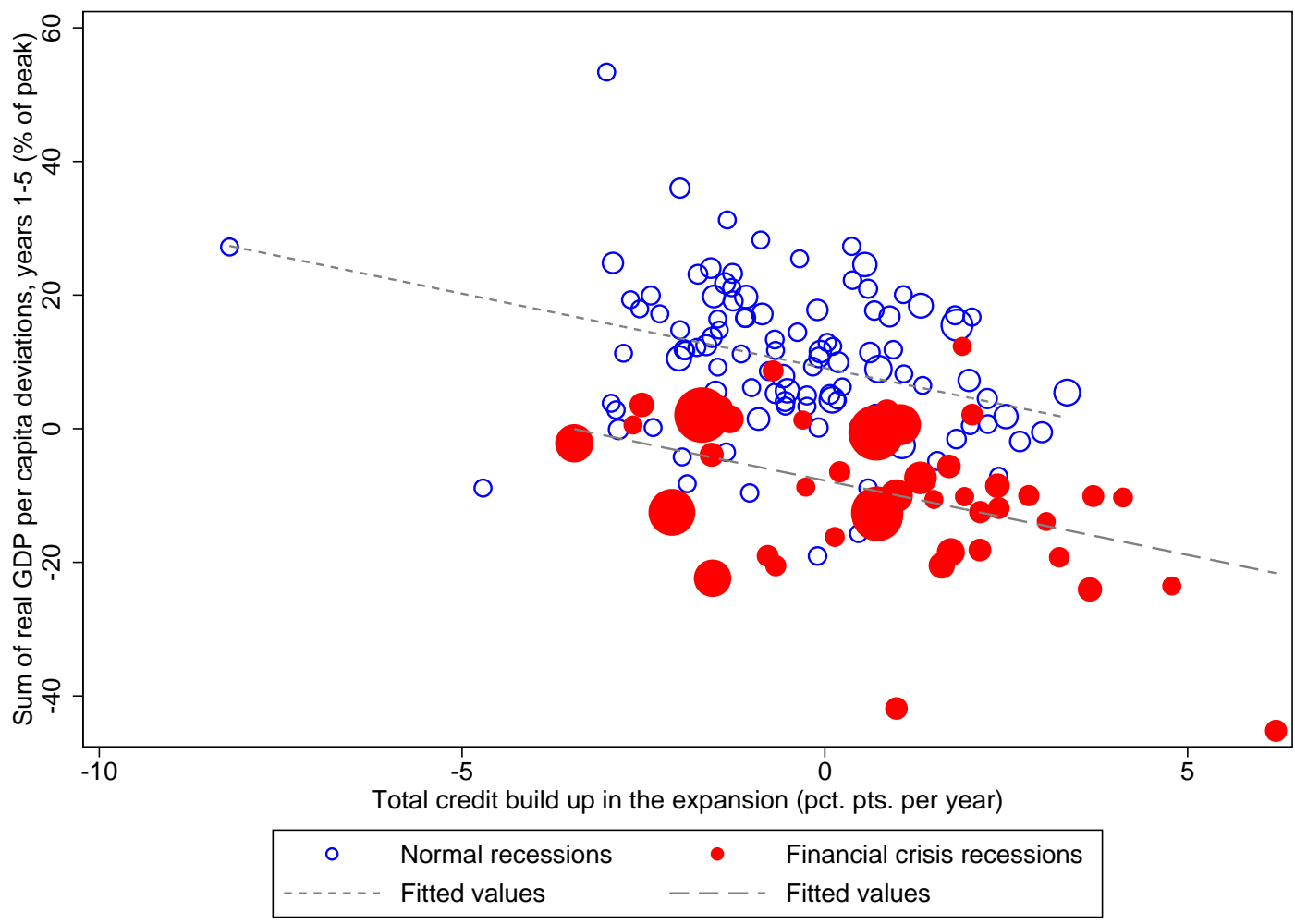

Notes: Full sample 1870-2010 (excluding world wars). The size of the circle indicates the weight of that observation based on the inverse propensity score weight from the logit models estimated over 1870-1939 (excluding WWI), and 1948-2010. The slope estimates for each sub-population (normal versus financial crisis recessions) indicate the effect of credit buildups in the expansions on real GDP per capita five years after the recession starts.

credit buildups are relatively small (e.g., the two observations at the bottom of the figure).

The negative slope coefficients for the weighted subsamples imply that the larger the credit buildup in the expansion the weaker is the subsequent recovery after the recession. The large and statistically significant intercept difference between the two regression lines for the subsamples measures the average difference between the aftermath of financial crisis and normal recessions, controlling for all measurable economic factors. This summary effect is consistent with the annual paths in Tables 6 and 7 , and qualitatively large: it again adds up to about 20 percent for the sum of log real GDP per capita deviations over 5 years, i.e., a loss of 4 percent of output per year in that window. 
Table 7: Local projections: path of real GDP per capita in normal vs. financial recessions and the role of credit using inverse propensity-score weighting regression adjustment (IPWRA)

\begin{tabular}{lccccc}
\hline \hline Sample = All Recessions & Year 1 & Year 2 & Year 3 & Year 4 & Year 5 \\
\hline Normal recession & $-1.65^{* * *}$ & 0.02 & $1.96^{* * *}$ & $3.43^{* * *}$ & $5.12^{* * *}$ \\
& $(0.23)$ & $(0.42)$ & $(0.46)$ & $(0.48)$ & $(0.46)$ \\
Financial recession & $-2.41^{* * *}$ & $-3.13^{* * *}$ & $-2.50^{* * *}$ & -1.17 & -0.48 \\
& $(0.34)$ & $(0.59)$ & $(0.78)$ & $(0.75)$ & $(0.54)$ \\
Private credit & -0.15 & -0.32 & $-0.46^{* *}$ & $-0.72^{* *}$ & $-0.46^{* *}$ \\
& $(0.17)$ & $(0.32)$ & $(0.21)$ & $(0.25)$ & $(0.17)$ \\
\hline$R^{2}$ & 0.638 & 0.442 & $0.43^{2}$ & 0.433 & 0.538 \\
$H_{0}:$ Normal = Financial; $p$-value & 0.19 & 0.01 & 0.00 & 0.00 & 0.00 \\
Observations & 150 & 150 & 150 & 150 & 150 \\
\hline \hline
\end{tabular}

Notes: ${ }^{* * *} \mathrm{p}<0.01,{ }^{* *} \mathrm{p}<0.05,{ }^{*} \mathrm{p}<$ o.1. Robust standard errors in parentheses. Country fixed effects not shown. Full sample: 1870 to 2010. Excludes world wars. The table compares the conditional average path of a normal recession against that of a financial crisis recession. Each panel tests equality of the conditional mean in normal and financial crisis recessions by reporting the $\mathrm{p}$-value of the test. The variables are weighted by the inverse propensity score for the probability of observing a financial crisis recession instead of a normal recession. See text.

Table 7 builds on the intuition in Figure 7 and shows that debt overhang is a regular phenomenon of the modern business cycle. Estimates of the credit buildup indicator are sometimes estimated inaccurately even though the economic effects are quite sizable. The coefficient estimates on the credit buildup indicator are statistically significant at conventional levels in Years 3, 4 and 5. At its peak effect in Year 4 every additional I percentage point per year of credit accumulation above the country specific mean is associated with about 0.7 percent lower real per capita GDP relative to the start of the recession 8 Moreover, the summary statistics reported in Table 5 suggest that the experiment based on 1 percentage point per year of credit buildup is rather conservative since the sample standard deviation of this variable is about 2 percentage points.

These results confirm the findings in Jordà, Schularick, and Taylor (2013) using new data and more sophisticated techniques. On an aggregate level credit booms are associated with deeper recessions and slower recoveries. Put differently, credit bites back.

\footnotetext{
${ }^{8}$ That effect is larger in the pre-WWII sample at over one percent (although with more volatile acrosshorizon dynamics), and about the same post-WWII. See the appendix for the analysis in Table 7 broken down by pre- and post-WWII samples.
} 
However, even controlling for these effects financial crisis recessions are still dramatically more costly then normal recessions, with losses mounting to $1 / 5$ of annual real GDP over 5 years. In the next section we turn to a more granular analysis and examine if and how the composition of credit has an effect on the dynamics of the business cycle.

\subsection{The Aftermath of Mortgage Booms}

Up to now we have estimated recession paths based on total credit-but is all credit the same? Are overhangs from mortgage booms particularly severe?

In this section we maintain the baseline IPWRA specification in expression (5) but split the credit variable into two components: mortgage lending versus non-mortgage lending. Mortgage lending includes residential and commercial real estate lending. Nonmortgage lending is a less homogeneous category that includes business lending and other unsecured lending such as consumer finance. As before, both enter the regressions as the rate of change of each type of lending in the previous expansion (as a ratio to GDP and in percentage points per year) to normalize differences in the duration of expansions. Each variable is measured in deviation from country-specific means.

Table 8 extends the analysis in Table 7 using each credit component separately. In addition, it reports how in this case we find somewhat differentiated results when the full sample is broken down by two subsamples separated by WWII.

First, as in Tables 6 and 7 , the null hypothesis that the average paths conditional on controls and country-fixed effects in normal and financial crisis recessions are the same is comfortably rejected, except as before in Year 1. Over the five-year window the output gap between the two paths cumulates to about $1 / 5$ of annual output which still cannot be explained by the observable macroeconomic controls. Second, and in contrast with the results above, the regressions show that the dynamics of credit changed substantially after WWII so we report results for the full sample and two subperiods. The results from the full sample reported in panel (a) of Table 8 show scant evidence of a role for mortgage 
or non-mortgage credit. The reason why can be found in the sub-sample analysis.

Mortgage lending has economically important but imprecisely estimated effects whereas non-mortgage lending has are more precisely estimated effects in the preWWII sample. Still, the effect goes in the same direction for both types of lending. The faster the pace of lending during the expansion, the worse the subsequent recession. However, mirroring the long-run structural shift towards mortgage lending, a different picture emerges for the post-WWII sample: mortgage lending effects are now estimated precisely whereas the effects of non-mortgage lending are economically and statistically insignificant (and often have a perverse positive sign). We now comfortably reject the null that the marginal effects of mortgage and non-mortgage lending are the same. After WWII the overhang from mortgage booms is severe and long-lasting, in line with the growing importance of mortgage lending in overall credit discussed above.

Based on the results in Table 8 , in Figure 8 we present cumulated responses for real GDP per capita, the ratio of investment to GDP, and the ratio of total lending to GDP.

Table 8: Local projections: path of real GDP per capita in normal vs. financial recessions and the role of mortgage and non-mortgage credit using inverse propensity-score weighting regression adjustment (IPWRA)

\begin{tabular}{|c|c|c|c|c|c|}
\hline (a) All recessions & Year 1 & Year 2 & Year 3 & Year 4 & Year 5 \\
\hline Normal recession & $\begin{array}{c}-1.66^{* * *} \\
(0.21)\end{array}$ & $\begin{array}{l}-0.07 \\
(0.46)\end{array}$ & $\begin{array}{c}1.98^{* * *} \\
(0.48)\end{array}$ & $\begin{array}{c}3.43^{* * *} \\
(0.57)\end{array}$ & $\begin{array}{c}5.08^{* * *} \\
(0.54)\end{array}$ \\
\hline Financial recession & $\begin{array}{c}-2.39^{* * *} \\
(0.30)\end{array}$ & $\begin{array}{c}-3.07^{* * *} \\
(0.62)\end{array}$ & $\begin{array}{c}-2.51^{* * *} \\
(0.75)\end{array}$ & $\begin{array}{l}-1.06 \\
(0.73)\end{array}$ & $\begin{array}{l}-0.42 \\
(0.54)\end{array}$ \\
\hline Mortgage credit & $\begin{array}{c}0.16 \\
(0.17)\end{array}$ & $\begin{array}{l}-0.43 \\
(0.29)\end{array}$ & $\begin{array}{l}-0.59 \\
(0.53)\end{array}$ & $\begin{array}{l}-1.26^{*} \\
(0.61)\end{array}$ & $\begin{array}{l}-0.69 \\
(0.87)\end{array}$ \\
\hline Nonmortgage credit & $\begin{array}{l}-0.25 \\
(0.17)\end{array}$ & $\begin{array}{l}-0.29 \\
(0.39)\end{array}$ & $\begin{array}{l}-0.37 \\
(0.28)\end{array}$ & $\begin{array}{l}-0.55 \\
\text { (o.39) }\end{array}$ & $\begin{array}{l}-0.40 \\
(0.36)\end{array}$ \\
\hline$R^{2}$ & 0.651 & 0.464 & 0.438 & 0.434 & 0.535 \\
\hline$H_{0}:$ Normal $=$ Financial $; p$-value & 0.16 & 0.01 & 0.00 & 0.00 & 0.00 \\
\hline$H_{0}:$ Mortg $=$ NonMortg; $p$-value & 0.05 & 0.73 & 0.73 & 0.42 & 0.81 \\
\hline Observations & 148 & 148 & 148 & 148 & 148 \\
\hline
\end{tabular}

Table continued on next page. 
Table 8 , Continued

\begin{tabular}{lccccc}
\hline \hline (b) Pre-WWII recessions & Year 1 & Year 2 & Year 3 & Year 4 & Year 5 \\
\hline Normal recession & $-2.65^{* * *}$ & $-1.75^{* *}$ & 0.67 & 0.04 & $2.30^{*}$ \\
& $(0.43)$ & $(0.68)$ & $(0.89)$ & $(1.26)$ & $(1.15)$ \\
Financial recession & $-2.73^{* * *}$ & $-3.88^{* * *}$ & $-4.04^{* * *}$ & $-3.65^{* * *}$ & $-3.08^{* *}$ \\
& $(0.62)$ & $(1.17)$ & $(1.10)$ & $(0.95)$ & $(1.01)$ \\
Mortgage credit & 0.19 & -0.68 & 0.07 & -2.14 & -1.69 \\
& $(0.41)$ & $(0.79)$ & $(1.09)$ & $(1.52)$ & $(2.06)$ \\
Nonmortgage credit & $-0.27^{*}$ & -0.45 & -0.29 & $-0.81^{* *}$ & -0.28 \\
& $(0.13)$ & $(0.48)$ & $(0.33)$ & $(0.33)$ & $(0.44)$ \\
\hline$R^{2}$ & 0.771 & 0.605 & 0.557 & 0.551 & 0.593 \\
$H_{0}:$ Normal $=$ Financial; $p$-value & 0.93 & 0.17 & 0.01 & 0.04 & 0.00 \\
$H_{0}:$ Mortg $=$ NonMortg; $p$-value & 0.34 & 0.82 & 0.77 & 0.43 & 0.55 \\
Observations & 71 & 71 & 71 & 71 & 71 \\
\hline \hline c) Post-WWII recessions & Year 1 & Year 2 & Year 3 & Year 4 & Year 5 \\
\hline Normal recession & $-1.14^{* * *}$ & -0.15 & $2.13^{* * *}$ & $4.45^{* * *}$ & $6.61^{* * *}$ \\
& $(0.20)$ & $(0.31)$ & $(0.51)$ & $(0.61)$ & $(0.63)$ \\
Financial recession & $-2.04^{* * *}$ & $-3.50^{* * *}$ & $-2.28^{* * *}$ & $-1.55^{*}$ & -0.52 \\
& $(0.33)$ & $(0.54)$ & $(0.65)$ & $(0.78)$ & $(0.88)$ \\
Mortgage credit & 0.20 & -0.43 & $-1.46^{* * *}$ & $-2.09^{* * *}$ & $-2.46^{* *}$ \\
Nonmortgage credit & $(0.39)$ & $(0.42)$ & $(0.43)$ & $(0.56)$ & $(1.06)$ \\
\hline$R^{2}$ & -0.07 & 0.07 & -0.01 & 0.09 & 0.08 \\
$H_{0}:$ Mortg $=$ NonMortg; $p$-value & 0.63 & 0.25 & 0.06 & 0.03 & 0.10 \\
Observations & 77 & 77 & 77 & 77 & 77 \\
\hline \hline Notes: & 0.837 & $(0.26)$ & $(0.49)$ & $(0.56)$ & $(0.62)$ \\
\hline
\end{tabular}

Notes: ${ }^{* * *} \mathrm{p}<0.01,{ }^{* *} \mathrm{p}<0.05,{ }^{*} \mathrm{p}<$ 0.1. Robust standard errors in parentheses. Country fixed effects and controls not shown. Pre-WWI sample: 1870 to 1939 across 17 countries. Excludes WWI. Post-WWII sample: 1948-2010 across 17 countries. Each panel compares the conditional average path of a normal recession with the path in a financial crisis recession. In addition, it considers the effect of mortgage and non-mortgage credit buildups during the expansion as separate controls. The table provides two formal tests. First, it tests the equality of the conditional mean in normal and financial crisis recessions. Second, it tests that excess mortgage and non-mortgage credit have the same effect. The local projections are weighted by the inverse propensity score for the probability of observing a financial crisis recession instead of a normal recession. See text. 
The solid lines in the figure refer to the average conditional path in normal recessions (displayed in solid blue along with a grey shaded $95 \%$ confidence region) and in financial crisis recessions (displayed in solid red). For each type of recession we also modify the average path by considering model predictions under an alternative (above average) level of the credit buildup in the preceding expansion. The dotted lines correspond to the responses associated with a +1 s.d. acceleration of non-mortgage credit growth whereas the dashed line corresponds to a +1 s.d. boom of mortgage credit.

The first row of Figure 8 corresponds to the full 1870 to 2010 sample, the second row to the pre-WWII sample, and the third row to the post-WWII sample. Notice that the pre-WWII sample includes the Great Depression which helps explain the slower trends in general and the particularly severe paths of GDP and investment. Overall, the responses for each type of recession and for each variable are nicely aligned with economic intuition. It is evident that in financial crisis recessions output, investment, and credit are much more strongly affected than in normal recessions. It typically takes five years for economies to regain their previous peak output after a systemic financial crisis and even longer for investment.

Importantly, the figures also underscore the main lesson from Table 8 mortgage debt plays a key role in explaining the drag from debt overhang in the post-WWII decades. Comparing the responses for the post-WWII sample (bottom row) with either the full sample (top row) or the pre-WWII sample (middle row) reveals that mortgage booms lead to greater post-crisis drag on growth. These negative effects on the pace of the recovery are present both in normal recessions and in financial crisis recessions. Since WWII both normal and financial recessions tend to be considerably deeper and the recovery much slower when the preceding boom saw a strong expansion of mortgage debt.

Non-mortgage credit booms, by contrast, have virtually no effect on the path of the recession nowadays as shown in the bottom row of Figure 8. The dotted lines almost always lie on top of the solid lines. Yet matters are strikingly different for real estate credit 
Figure 8: Conditional cumulated responses for real GDP per capita, the ratio of investment to GDP, and the ratio of total lending to GDP from the start of the recession as a function of the type of recession and mortgage and non-mortgage credit

\section{Cumulative Change From the Start of the Recession}
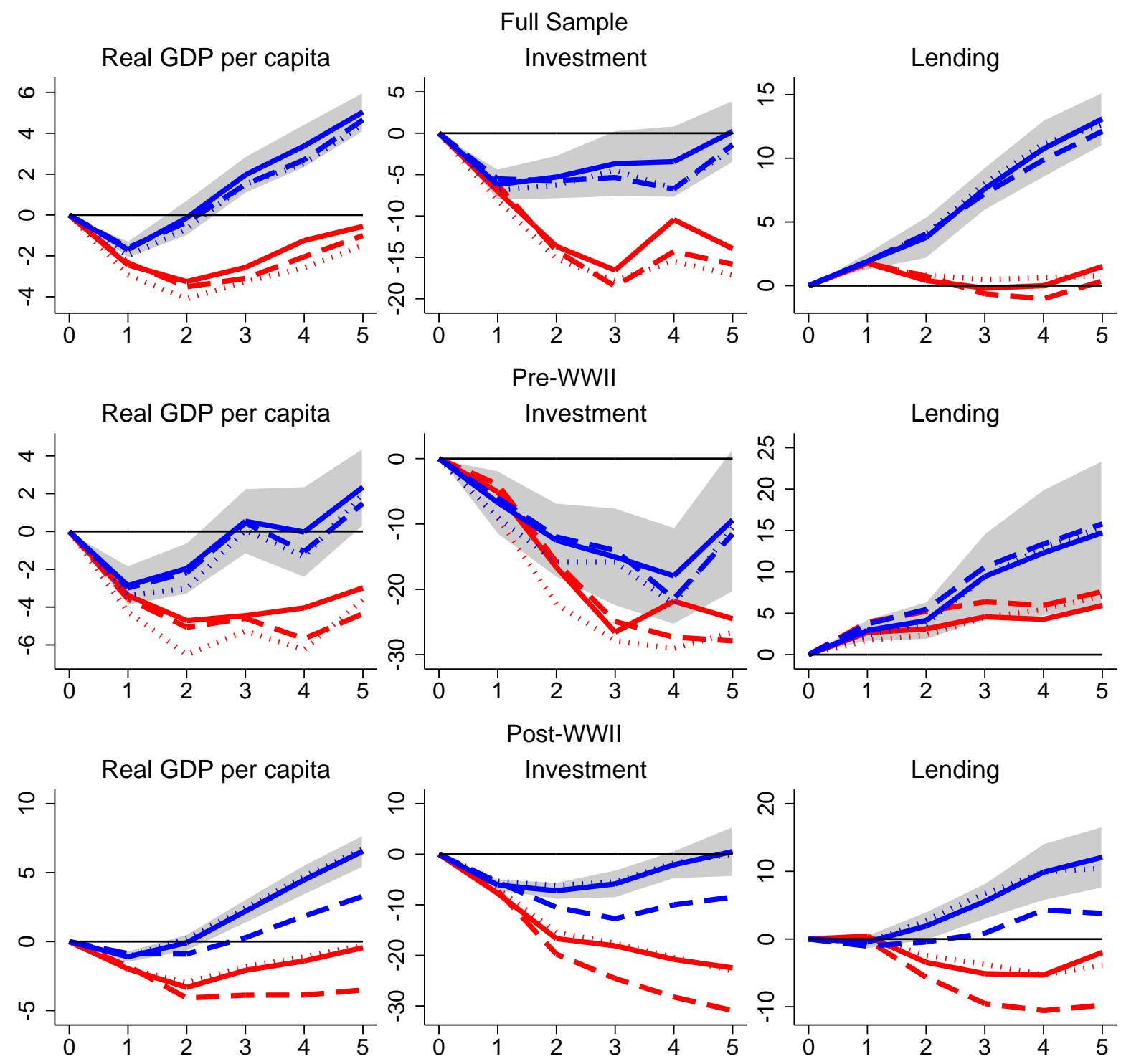

Notes: Samples: 1870-2010 (excluding world wars), 1870-1939 (excluding WWI), and 1948-2010. Scales matched by column but allowed to vary across variables. Each path shows IPWRA estimates of the cumulative change relative to peak for years $1-5$ of the recession/recovery period under different experiments. The solid line with shaded region refers to the average path in normal recessions. The solid line without shaded region refers to financial crisis recessions. The shaded region is a $95 \%$ confidence interval. The dotted lines refer to the path in a normal/financial crisis recession when non-mortgage credit during the expansion grew at the mean plus one standard deviation. The dashed lines refer to the path in a normal/financial crisis recession when mortgage credit during the expansion grew at the mean plus one standard deviation. The IPWRA estimates are conditional on the full set of macroeconomic aggregates and their lags, with paths evaluated at the means. See text. 
booms. By Year 5 , real GDP is about $4 \%$ lower than it would otherwise be-regardless of the type of recession. The effects are even more dramatic when considering investment. The difference between the average path and the post-mortgage credit boom path are close to $10 \%$ after Year 5, potentially driven by a collapse in housing investment.

The estimates reported in Figure 8 are based on our IPWRA estimates and are the closest we can come to showing how the accumulation of credit (mortgage and otherwise) affects the path of the recession and recovery, even after controlling for crisis endogeneity. Although a financial crisis still makes the recession worse beyond other observable factors, comparing the results reported across Tables $6-8$ we note that this effect becomes increasingly more attenuated even if it never completely disappears.

Summing up, the local projections demonstrate that the aftermath of credit booms is characterized by recessions that are deeper and recoveries that are slower than normal. However, our new disaggregated credit data adds important nuances to the debt overhang story. Since WWII, it was in particular the overhang from mortgage booms that was associated with more painful recessions and protracted recoveries.

\section{CONCLUSIONS}

This paper presented three new important insights into long-run credit dynamics in advanced economies. These insights are the result of combining modern methods of statistical analysis with the painstaking construction of a new dataset. We expect that the value of this dataset will transcend the present paper and that it will become an important resource for macroeconomic research going forward. The new insights also have important implications for macroeconomics researchers and policymakers alike and they can be summarized as follows.

First, we found that in the second half of the 2oth century, banks and households have been heavily leveraging up through mortgages. Mortgage credit on the balance sheets of banks has been the driving force behind the increasing financialization of advanced 
economies. In relation to GDP, non-mortgage bank lending to companies and households has remained stable, with virtually all of the increase in the size of the financial sector stemming from a boom in mortgage lending to households. Household leverage ratios (mortgage debt divided by the value of the housing stock) have increased substantially in many economies over the 2oth century. About two thirds of the business of banking today consists of the intermediation of savings to the household sector for the purchase of real estate. At the beginning of the 2oth century mortgage lending accounted for less than a third of the typical bank's loan book.

Second, we showed that the growth of mortgage credit has important implications for the sources of financial fragility in advanced economies, and hence for macroeconomic policies. Mortgage booms are an important source of financial instability in the post-WWII era, and mortgages have growing weight in total financial sector activity. We present evidence that the changing nature of financial intermediation has shifted the locus of crisis risk towards mortgage lending booms. This is an important new fact to be considered in the design of macro-prudential policies.

Third, we demonstrated that mortgage credit has also increasingly left its mark on business cycle dynamics. In the post-WWII period the aftermath of mortgage booms gone bust is marked by considerably slower growth rates, irrespective of whether a financial crisis occured or not. Non-mortgage credit no longer appears to have such an effect. Contemporary business cycles seem to be increasingly shaped by the dynamics of mortgage credit, with non-mortgage lending playing only a minor role.

Overall, the findings of this paper call for a differentiated perspective on credit growth and on the implications that this differentiation has for financial stability, macroeconomic policies, and financial regulation. Important insights into the sources of financial fragility and the role of credit in the business cycle would be missed without a disaggregated perspective on the various types of credit and their development over the course of modern macroeconomic history. 


\section{REFERENCES}

Acemoglu, Daron, Simon Johnson, James Robinson, and Yunyong Thaicharoen. 2003. Institutional Causes, Macroeconomic Symptoms: Volatility, Crises and Growth. Journal of Monetary Economics 5O(1): 49-123.

Admati, Anat, and Martin Hellwig. 2013. The Bankers' New Clothes: What's Wrong with Banking and What to Do about It. Princeton, N.J.: Princeton University Press.

Aikman, David, Andrew G. Haldane, and Benjamin D. Nelson. 2014. Curbing the Credit Cycle. Economic Journal. doi:10.1111/ecoj.12113.

Angrist, Joshua D., Òscar Jordà, and Guido Kuersteiner. 2013. Semiparametric Estimates of Monetary Policy Effects: String Theory Revisited. NBER working paper 19355.

Bank for International Settlements. 2013. Long Series on Credit to Private Non-financial Sectors. https://www.bis.org/statistics/credtopriv.htm.

Barro, Robert J., and José F. Ursúa. 2008. Macroeconomic Crises since 1870. Brookings Papers on Economic Activity 39(1): 255-335.

Bordo, Michael D., Barry Eichengreen, Daniela Klingebiel, and María Soledad Martínez-Pería. 2001. Is the Crisis Problem Growing More Severe? Economic Policy 16(32): 53-83.

Cerra, Valerie, and Sweta C. Saxena. 2008. Growth Dynamics: The Myth of Economic Recovery. American Economic Review 98(1): 439-457.

Fetter, Daniel K. 2013. How Do Mortgage Subsidies Affect Home Ownership? Evidence from the Mid-century GI Bills. American Economic Journal: Economic Policy 5(2) 111-47.

Gaertner, Katharina. 2012. White Picket Finance: The Making of the U.S. Mortgage Market, 1932-1960. In Public Policies and the Direction of Financial Flows, edited by Hubert Bonin, Alfredo Gigliobianco, Niels-Viggo Haueter, and Harold James. Bucharest: European Association for Banking and Financial History and National Bank of Romania.

Glynn, Adam N. and Kevin M. Quinn. 2010. An Introduction to the Augmented Inverse Propensity Weighted Estimator. Political Analysis 18(1): 36-56.

Godechot, Olivier. 2012. Is Finance Responsible for the Rise in Wage Inequality in France? Socio-Economic Review 10(3): 447-70.

Goldsmith, Raymond W. 1985. Comparative National Balance Sheets: A Study of Twenty Countries, 1688-1979 Chicago: University of Chicago Press.

Greenwood, Robin, and David Scharfstein. 2013. The Growth of Modern Finance. Journal of Economic Perspectives, 27(2): 3-28.

Hoffman, Philip T., Gilles Postel-Vinay, and Jean-Laurent Rosenthal. 200o. Priceless Markets: The Political Economy of Credit in Paris, 1660-1870. Chicago: University of Chicago Press.

Johnson, Simon, and James Kwak. 2010. 13 Bankers: The Wall Street Take Over and the Next Financial Meltdown. New York: Vintage Books.

Jordà, Òscar, and Alan M. Taylor. 2011. Performance Evaluation of Zero Net-Investment Strategies. 
NBER Working Paper 17150.

Jordà, Òscar, and Alan M. Taylor. 2013. The Time for Austerity: Estimating the Average Treatment Effect of Fiscal Policy. NBER working paper 19414.

Jordà, Òscar, Moritz Schularick, and Alan M. Taylor. 2013. When Credit Bites Back. Journal of Money, Credit and Banking 45(s2): 3-28.

Laeven, Luc, and Fabian Valencia. 2008. Systemic Banking Crises: A New Database. IMF Working Paper 08/224.

Laeven, Luc, and Fabian Valencia. 2012. Systemic Banking Crises Database: An Update. IMF Working Paper 12/163.

Lunceford, Jared K., and Marie Davidian. 2004. Stratification and Weighting via the Propensity Score in Estimation of Causal Treatment Effects: A Comparative Study. Statistics in Medicine 23(19): 2937-6o.

Maddison, Angus. 2005. Measuring and Interpreting World Economic Performance, 1500-2001. Review of Income and Wealth 51(1): 1-35.

Mian, Atif, and Amir Sufi. 2014. House of Debt. Chicago: University of Chicago Press.

Mian, Atif, and Amir Sufi. 2010. Household Leverage and the Recession of 2007-09. IMF Economic Review 58(1): 74-117.

Mitchell, Brian R. 2008a. International Historical Statistics: Africa, Asia, and Oceania, 1750-2005. 5th Edition. New York: Macmillan.

Mitchell, Brian R. 2008b. International Historical Statistics: Europe, 1750-2005. 6th Edition. New York, Macmillan.

Mitchell, Brian R. 2008c. International Historical Statistics: The Americas, 1750-2005. 6th Edition. New York: Macmillan.

Phillipon, Thomas, and Ariell Reshef. 2013. An International Look at the Growth of Modern Finance. Journal of Economic Perspectives, 27(2): 73-96.

Piketty, Thomas. 2013. On the Long-Run Evolution of Inheritance: France, 1820-2050. Quarterly Journal of Economics, 126(3): 1071-1131.

Piketty, Thomas, and Gabriel Zucman. 2013. Capital is Back: Wealth-Income Ratios in Rich Countries, 1700-2010. CEPR Discussion Paper 9588.

Reinhart, Carmen M., and Kenneth S. Rogoff. 2009. This Time is Different: Eight Centuries of Financial Folly. Princeton, N.J.: Princeton University Press.

Schularick, Moritz, and Alan M. Taylor. 2012. Credit Booms Gone Bust: Monetary Policy, Leverage Cycles, and Financial Crises, 1870-2008. American Economic Review 102(2): 1029-61.

Turner, Adair. 2010. What do Banks Do? Why do Credit Booms and Busts Occur and What Can Public Policy Do About It? In The Future of Finance: The LSE Report by Adair Turner et al. London: London School of Economics and Political Science.

Wooldridge, Jeffrey M. 2010. Econometric Analysis of Cross Section and Panel Data. 2nd ed. Cambridge, Mass.: MIT Press. 


\section{A. Appendix: Dates of Systemic Financial Crises, 1870-2011}

The crisis prediction classification models in the paper employ data on all systemic financial crises from 1870 to 2011. Dates of systemic financial crises based on Jordà, Schularick, and Taylor (2011) and Schularick and Taylor (2012), sources therein, and updates. See text. AUS stands for Australia, BEL for Belgium, CAN for Canada, CHE for Switzerland, DEU for Germany, DNK for Denmark, ESP for Spain, FIN for Finland, FRA for France, GBR for the U.K., ITA for Italy, JPN for Japan, NLD for The Netherlands, NOR for Norway, PRT for Portugal, SWE for Sweden, USA for the United States.

Appendix Table 1: Dates of systemic financial crises, 1870-2011

\begin{tabular}{ll}
\hline \hline AUS & 1893,1989 \\
BEL & $1870,1885,1925,1931,1939,2008$ \\
CAN & $1873,1907,1923$ \\
CHE & $1870,1910,1931,1991,2008$ \\
DEU & $1873,1891,1901,1907,1931,2008$ \\
DNK & $1877,1885,1908,1921,1987,2008$ \\
ESP & $1883,1890,1913,1920,1924,1931,1978,2008$ \\
FIN & $1878,1900,1921,1931,1991$ \\
FRA & $1882,1889,1930,2008$ \\
GBR & $1873,1890,1974,1984,1991,2007$ \\
ITA & $1873,1887,1893,1907,1921,1930,1935,1990,2008$ \\
JPN & $1882,1900,1904,1907,1913,1927,1997$ \\
NLD & $1893,1907,1921,1939,2008$ \\
NOR & $1899,1922,1931,1988$ \\
PRT & $1890,1920,1923,1931,2008$ \\
SWE & $1878,1907,1922,1931,1991,2008$ \\
USA & $1873,1884,1893,1907,1929,1984,2007$ \\
\hline \hline
\end{tabular}

\section{B. Appendix: Dates of Normal and Financial Crisis Recessions, 1870-2006}

The local projection analysis in the paper employs business cycle peaks from 1870 to 2006, excludes windows around the two world wars, reports projections out to 5 years ahead, and uses the annual panel sample data where the last year's projections from 2006 end in 2011. As a result, peaks from the 2007-2011 period are not used in the sample, meaning that the empirical work does not include the global financial crisis as an in-sample event. The peak dates which we use are as shown in the table below where " $\mathrm{N}$ " denotes a normal business cycle peak and " $\mathrm{F}$ " denotes a peak associated with a systemic financial crisis, that is, a crisis within \pm 2 years of the peak. The peak-trough dating method follows Jordà, Schularick, and Taylor (2011) and uses the Bry and Boschan (1971) algorithm. 
Appendix Table 2: Dates of normal and financial crisis recession peaks, 1870-2006

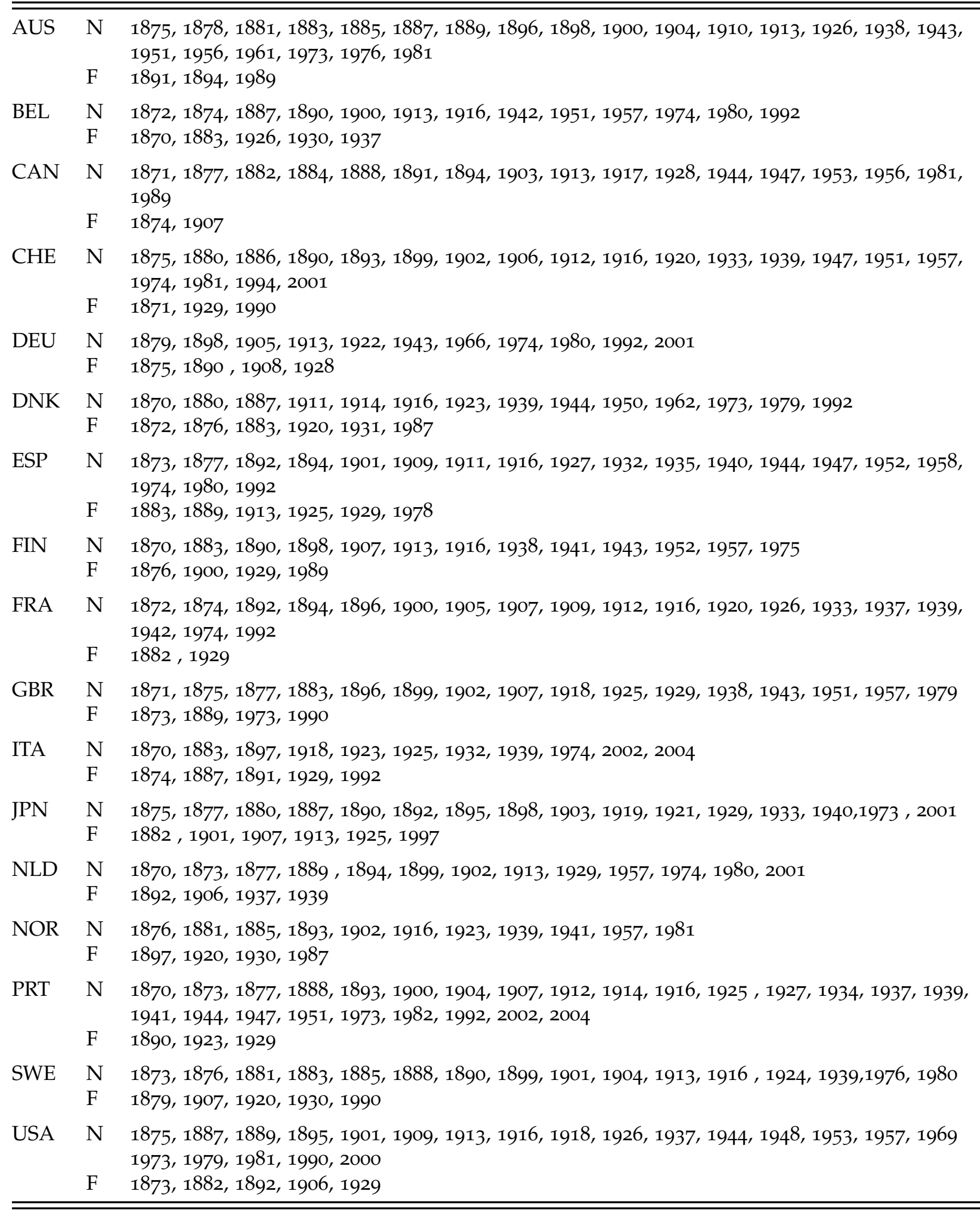




\section{Appendix: Subsample Results for Regressions in Tables 6 and 7}

We report results when the regressions in Tables 6 and 7 are estimated separately for Pre-WWII and Post-WWII Recessions. The subsample regressions in Table 8 appear in the main text since there are significant differences in the impact of different credit measures across periods. In these two tables, however, such differences are not present.

Appendix Table 3 reports the simple normal versus financial path differences with no other control variables as in Table 6. The only qualitative difference between the Pre-WWII and PostWWII Recessions arises from the lower average trend growth (plus the incidence of The Great Depression) in the earlier Pre-WWII sample, which lowers each intercept by about 0.9 percentage points per year on average. But with respect to the Normal versus Financial coefficient differences, the findings from the full sample remain intact.

Appendix Table 4 reports the normal versus financial path differences and the effect of the total credit control variable as in Table 7. The same normal versus financial differences remain, but the small sample size leads to imprecise estimates of the total credit coefficient. With no significant differences here in the total credit coefficient for the the Pre-WWII and Post-WWII Recessions, the findings of Table 7 are not overturned, and the tighter confidence intervals obtained from the full sample estimates are to be preferred.

Appendix Table 3: Local projections: path of real GDP per capita in normal v. financial recessions using inverse propensity-score weighting (IPW), subsample analysis for pre-WWII and post-WWII periods

\begin{tabular}{lccccc}
\hline \hline (a) Sample = Pre-WWII Recessions & Year 1 & Year 2 & Year 3 & Year 4 & Year 5 \\
\hline Normal recession & $-3.06^{* * *}$ & $-1.76^{* *}$ & 0.29 & -0.41 & 1.91 \\
& $(0.51)$ & $(0.68)$ & $(0.75)$ & $(1.38)$ & $(1.15)$ \\
Financial recession & $-3.78^{* * *}$ & $-5.33^{* * *}$ & $-4.89^{* * *}$ & $-4.89^{* * *}$ & $-3.43^{* *}$ \\
& $(0.68)$ & $(1.38)$ & $(1.08)$ & $(1.31)$ & $(1.26)$ \\
\hline$R^{2}$ & 0.708 & 0.476 & 0.544 & 0.495 & 0.581 \\
$H_{0}:$ Normal = Financial; $p$-value & 0.50 & 0.04 & 0.01 & 0.03 & 0.00 \\
Observations & 73 & 73 & 73 & 73 & 73 \\
\hline \hline (b) Sample = Post-WWII Recessions & Year 1 & Year 2 & Year 3 & Year 4 & Year 5 \\
\hline Normal recession & $-1.10^{* * *}$ & -0.15 & $2.14^{* * *}$ & $4.40^{* * *}$ & $6.50^{* * *}$ \\
& $(0.21)$ & $(0.34)$ & $(0.46)$ & $(0.58)$ & $(0.66)$ \\
Financial recession & $-2.01^{* * *}$ & $-3.15^{* * *}$ & $-1.78^{* *}$ & -1.00 & 0.04 \\
& $(0.28)$ & $(0.48)$ & $(0.62)$ & $(0.76)$ & $(0.90)$ \\
\hline$R^{2}$ & 0.833 & 0.707 & 0.632 & 0.716 & 0.753 \\
$H_{0}:$ Normal $=$ Financial; $p$-value & 0.07 & 0.00 & 0.00 & 0.00 & 0.00 \\
Observations & 77 & 77 & 77 & 77 & 77 \\
\hline \hline Notes: & Robur &
\end{tabular}

Notes: ${ }^{* * *} \mathrm{p}<0.01,{ }^{* *} \mathrm{p}<0.05,{ }^{*} \mathrm{p}<0.1$. Robust standard errors in parentheses. Country fixed effects not shown. Panel (a): 1870-1939 sample. Panel (b) 1948-2010 sample. Each panel tests equality of the conditional mean in normal and financial crisis recessions by reporting the $p$-value of the test. The variables are weighted by the inverse propensity score for the probability of observing a financial crisis recession instead of a normal recession. See text. 
Appendix Table 4: Local projections: path of real GDP per capita in normal v. financial recessions and the role of credit using inverse propensity-score weighting regression adjustment (IPWRA), subsample analysis for pre-WWII and post-WWII periods

\begin{tabular}{|c|c|c|c|c|c|}
\hline (a) Sample = Pre-WWII Recessions & Year 1 & Year 2 & Year 3 & Year 4 & Year 5 \\
\hline Normal recession & $\begin{array}{c}-2.81^{* * *} \\
(0.46)\end{array}$ & $\begin{array}{l}-1.43^{*} \\
(0.73)\end{array}$ & $\begin{array}{c}0.45 \\
(0.76)\end{array}$ & $\begin{array}{l}-0.10 \\
(1.16)\end{array}$ & $\begin{array}{c}1.96 \\
(1.20)\end{array}$ \\
\hline Financial recession & $\begin{array}{c}-2.95^{* * *} \\
(0.56)\end{array}$ & $\begin{array}{c}-4.19^{* * *} \\
(1.02)\end{array}$ & $\begin{array}{c}-4.33^{* * *} \\
(0.97)\end{array}$ & $\begin{array}{c}-3.81^{* *} \\
(1.21)\end{array}$ & $\begin{array}{c}-3.22^{* *} \\
(1.16)\end{array}$ \\
\hline Private credit & $\begin{array}{l}-0.19 \\
(0.13)\end{array}$ & $\begin{array}{l}-0.53 \\
(0.41)\end{array}$ & $\begin{array}{l}-0.24 \\
(0.34)\end{array}$ & $\begin{array}{c}-1.06^{* * *} \\
(0.29)\end{array}$ & $\begin{array}{l}-0.52 \\
(0.37)\end{array}$ \\
\hline$R^{2}$ & 0.765 & 0.559 & 0.554 & 0.543 & 0.588 \\
\hline$H_{0}:$ Normal $=$ Financial $; p$-value & 0.87 & 0.04 & 0.01 & 0.03 & 0.00 \\
\hline Observations & 73 & 73 & 73 & 73 & 73 \\
\hline (b) Sample $=$ Post-WWII Recessions & Year 1 & Year 2 & Year 3 & Year 4 & Year 5 \\
\hline Normal recession & $\begin{array}{c}-1.13^{* * *} \\
(0.19)\end{array}$ & $\begin{array}{l}-0.16 \\
(0.34)\end{array}$ & $\begin{array}{c}2.06^{* * *} \\
(0.46)\end{array}$ & $\begin{array}{c}4 \cdot 33^{* * *} \\
(0.54)\end{array}$ & $\begin{array}{c}6.48^{* * *} \\
(0.55)\end{array}$ \\
\hline Financial recession & $\begin{array}{c}-2.06^{* * *} \\
(0.30)\end{array}$ & $\begin{array}{c}-3.16^{* * *} \\
(0.53)\end{array}$ & $\begin{array}{c}-1.77^{* *} \\
(0.71)\end{array}$ & $\begin{array}{l}-0.94 \\
(0.85)\end{array}$ & $\begin{array}{c}0.19 \\
(0.99)\end{array}$ \\
\hline Private credit & $\begin{array}{c}0.02 \\
(0.10) \\
\end{array}$ & $\begin{array}{l}-0.03 \\
(0.29) \\
\end{array}$ & $\begin{array}{l}-0.39 \\
(0.34) \\
\end{array}$ & $\begin{array}{l}-0.51 \\
(0.39) \\
\end{array}$ & $\begin{array}{l}-0.61 \\
(0.48) \\
\end{array}$ \\
\hline$R^{2}$ & 0.836 & 0.707 & 0.645 & 0.733 & 0.775 \\
\hline$H_{0}:$ Normal $=$ Financial $; p$-value & 0.07 & 0.00 & 0.00 & 0.00 & 0.00 \\
\hline Observations & 77 & 77 & 77 & 77 & 77 \\
\hline
\end{tabular}

Notes: ${ }^{* * *} \mathrm{p}<0.01,{ }^{* *} \mathrm{p}<0.05,{ }^{*} \mathrm{p}<0.1$. Robust standard errors in parentheses. Country fixed effects not shown. Panel (a): 1870-1939 sample. Panel (b) 1948-2010 sample. Each panel tests equality of the conditional mean in normal and financial crisis recessions by reporting the $\mathrm{p}$-value of the test. The variables are weighted by the inverse propensity score for the probability of observing a financial crisis recession instead of a normal recession. See text. 